\title{
New records of lithobiid centipedes from Siberia, Russia (Chilopoda: Lithobiomorpha: Lithobiidae)
}

\author{
Новые находки многоножек-костянок из Сибири, Россия \\ (Chilopoda: Lithobiomorpha: Lithobiidae)
}

\author{
P.S. Nefediev ${ }^{1,2,3}$, G.Sh. Farzalieva ${ }^{4,5}$ \\ П.С. Нефедьев ${ }^{1,2,3}$, Г.Ш. Фарзалиева ${ }^{4,5}$
}

\footnotetext{
${ }^{1}$ Altai State University, Lenin Avenue, 61, Barnaul 656049 Russia. E-mail: p.nefediev@mail.ru

${ }^{2}$ Tomsk State University, Lenin Avenue, 36, Tomsk 634050 Russia.

${ }^{3}$ Tigirek State Nature Reserve, Nikitina Street, 111, Barnaul 656049 Russia.

${ }^{4}$ Perm State University, Bukireva Street, 15, Perm 614600 Russia. E-mail: fgsh@psu.ru

${ }^{5}$ Perm Regional Museum, Monastyrskaya Street, 11, Perm 614000 Russia

1 Алтайский государственный университет, просп. Ленина, 61, Барнаул 656049 Россия.

${ }^{2}$ Томский государственный университет, просп. Ленина, 36, Томск 634050 Россия.

${ }^{3}$ Государственный природный заповедник «Тигирекский», ул. Никитина, 111, Барнаул 656049 Россия.

${ }^{4}$ Пермский государственный университет, ул. Букирева, 15, Пермь 614600 Россия.

${ }^{5}$ Пермский краеведческий музей, ул. Монастырская, 11, Пермь 614000 Россия.
}

KEY WORDS: lithobiid centipedes, Lithobiidae, Lithobius, Chinobius, Ezembius, Monotarsobius, fauna, new records, Siberia, Russia.

КЛЮЧЕВЫЕ СЛОВА: многоножки-костянки, Lithobiidae, Lithobius, Chinobius, Ezembius, Monotarsobius, фауна, новые находки, Сибирь, Россия.

ABSTRACT. Based on new material and previously unstudied collections, the distributions of 13 lithobiid species from Siberia have been refined. The subgenus Chinobius Matic, 1973 and two species, Lithobius (Ch.) opinatus (Zalesskaja, 1978) and L. (Ezembius) giganteus Sseliwanoff, 1881, are reported from western Siberia for the first time. Some species, $L$. (E.) giganteus Sseliwanoff, 1881, L. (Monotarsobius) fugax Stuxberg, 1876 and L. (M.) nordenskioeldii Stuxberg, 1876, are new to the Republic of Altai. The first data on the lithobiid fauna of the Republic of Khakassia, encompassing 5 species, are provided: L. (Ch.) opinatus (Zalesskaja, 1978), L. (E.) princeps Stuxberg, 1876, L. (M.) curtipes C.L. Koch, 1847, L. (M.) fugax Stuxberg, 1876 and L. (M.) worogowensis Eason, 1976. The distributions of all species encountered are mapped for the first time in the Siberian region.

How to cite this article: Nefediev P.S., Farzalieva G.Sh. 2020. New records of lithobiid centipedes from Siberia, Russia (Chilopoda: Lithobiomorpha: Lithobiidae) // Arthropoda Selecta. Vol.29. No.2. P.185-198. doi: 10.15298/arthsel. 29.2.03

РЕЗЮМЕ. По результатам обработки нового материала и необработанных ранее коллекций уточнено распространение в Сибири 13 видов многоножек-костянок. Подрод Chinobius Matic, 1973 и два вида, Lithobius (Ch.) opinatus (Zalesskaja, 1978) и L. (Ezembius) giganteus Sseliwanoff, 1881, формально впервые указываются для Западной Сибири. Виды
L. (E.) giganteus Sseliwanoff, 1881, L. (Monotarsobius) fugax Stuxberg, 1876 и L. (M.) nordenskioeldii Stuxberg, 1876 являются новыми для Республики Алтай. Приводятся первые данные по фауне костянок Республики Хакасия, включающей 5 видов: $L$. (Ch.) opinatus (Zalesskaja, 1978), L. (E.) princeps Stuxberg, 1876, L. (M.) curtipes C.L. Koch, 1847, L. (M.) fugax Stuxberg, 1876 и L. (M.) worogowensis Eason, 1976. Для всех видов впервые выполнено картирование ареалов в пределах Сибири.

\section{Introduction}

The first data on the lithobiid fauna of Siberia appeared in the second part of XIX century [Gerstfeldt, 1859; Stuxberg, 1876a, b; Haase, 1880; Sseliwanoff, $1880 \mathrm{a}, \mathrm{b}, 1881 \mathrm{a}, \mathrm{b}]$. The original descriptions of all species recorded in those papers were unsatisfactory, thus requiring redescriptions. A century later, Stuxberg's type material was revised by Eason [1976] with designations of lectotypes of several species. Despite all recent progress in the study of lithobiomorph centipedes in the Asian part of Russia [Molodova, 1972; Alekseeva, 1974; Kurcheva, 1977; Zalesskaja, 1978; Vorobiova, 1999; Nefediev, 2001; Rybalov, 2002; Vorobiova et al., 2002; Striganova, Poryadina, 2005; Sergeeva, 2010, 2013; Bukhkalo, Sergeeva, 2012; Nefediev, Aripov, 2013; Bukhkalo et al., 2014; Nefediev et al., 2016, 2017a, b, c, 2018, 2020; Dyachkov, 2017b; Farzalieva et al., 2017; Farzalieva, 2018; Farza- 


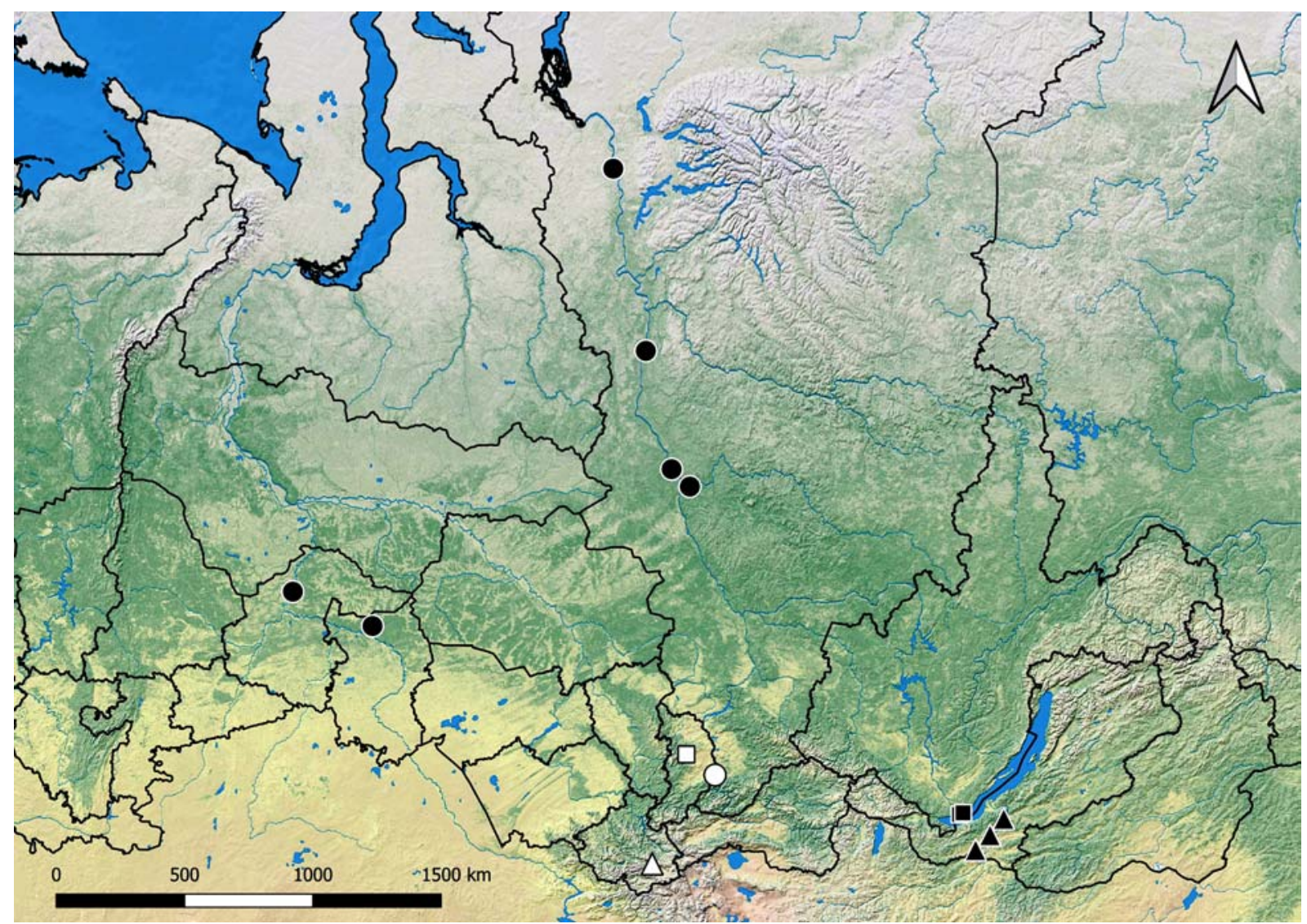

Fig. 1. Distributions of Lithobius (Chinobius) opinatus (Zalesskaja, 1978) (square), L. (Ezembius) giganteus Sseliwanoff, 1881 (triangle) and $L$. (E.) princeps Stuxberg, 1876 (circle) in Siberia. Previously known localities marked in black, new records given in white.

Рис. 1. Распространение Lithobius (Chinobius) opinatus (Zalesskaja, 1978) (квадрат), L. (Ezembius) giganteus Sseliwanoff, 1881 (треугольник) и L. (E.) princeps Stuxberg, 1876 (круг) в Сибири. Черным отмечены ранее известные места находок, новые находки отмечены белым.

lieva, Nefediev, 2018], the fauna of Lithobiomorpha of Siberia remains understudied.

The distribution maps were composed using QGIS 3.8.0Zanzibar.

The material treated herein has been deposited in the collections of the Perm State University (PSU), and the Altai State University, Barnaul, Russia (ASU). Literature references to the species concern Siberia only.

Abbreviations used: s.1. - same locality, p.t. — pitfall traps, b.h. - by hand, A.M. - A.B. Medvedev, A.P. A.P. Pavlov, D.P. - D.I. Pogrebnyak, E.G. - E.V. Gribanova (all Abakan, Russia), M.S. - M.V. Shcherbakov (Tomsk, Russia), N.V. - N.M. Vyatkina (Troitskoye, Altai Province, Russia), A.N. - A.P. Nefedieva, J.N. - J.S. Nefedieva, P.N. - P.S. Nefediev (all Barnaul, Russia), V.G. V.I. Gusarov, M.M. - M.F. Maurstad, V.L. - V. Løveng (all Oslo, Norway).

\section{Taxonomic part}

\section{Class Chilopoda}

\section{ORDER LITHOBIOMORPHA}

\author{
Family LITHOBIIDAE
}

Lithobius (Chinobius) opinatus (Zalesskaja, 1978) Map 1.

Chinobius opinatus Zalesskaja, 1978: 38, 39: figs.

MATERIAL EXAMINED. $1 \bigcirc^{7}, 1+1$ juv. (PSU-811), Russia, Republic of Khakassia, Ust-Abakan District, valley of Uibat River, $53.825765^{\circ} \mathrm{N}, 90.052647^{\circ} \mathrm{E}$, mixed forest, ca $700 \mathrm{~m}$ a.s.l., in litter, 18.VII.2012, leg. A.P.; 1 q (ASU), s.1., 18.VII.2018, leg. E.G.

DISTRIBUTION. Being originally described by Zalesskaja [1978] from the Irkutsk Area, this species has previously been known only from its terra typica.

REMARKS. This species is being reported from outside its type locality for the first time, and the above records are new to entire western Siberia, in particular, to the Republic of Khakassia, representing the westernmost ones.

Lithobius (Ezembius) giganteus Sseliwanoff, 1881 Map 1.

Lithobius giganteus — Zalesskaja, 1973, 1978: 130, 131: figsæ Alekseeva, 1974: 8.

MATERIAL EXAMINED. $1 \sigma^{7}, 1$ (PSU-1201), $10^{7}, 1$ \% (ASU), Russia, Republic of Altai, Kosh-Agach District, 14 air-km NW of Chagan-Uzun, floodplain of Chuya River, on right bank, $50.1650225^{\circ} \mathrm{N}, 88.195779^{\circ} \mathrm{E}$, stony steppe, under stones in grassy glades, 1650 m a.s.1., 11.VIII.2006, leg. P.N., J.N. 


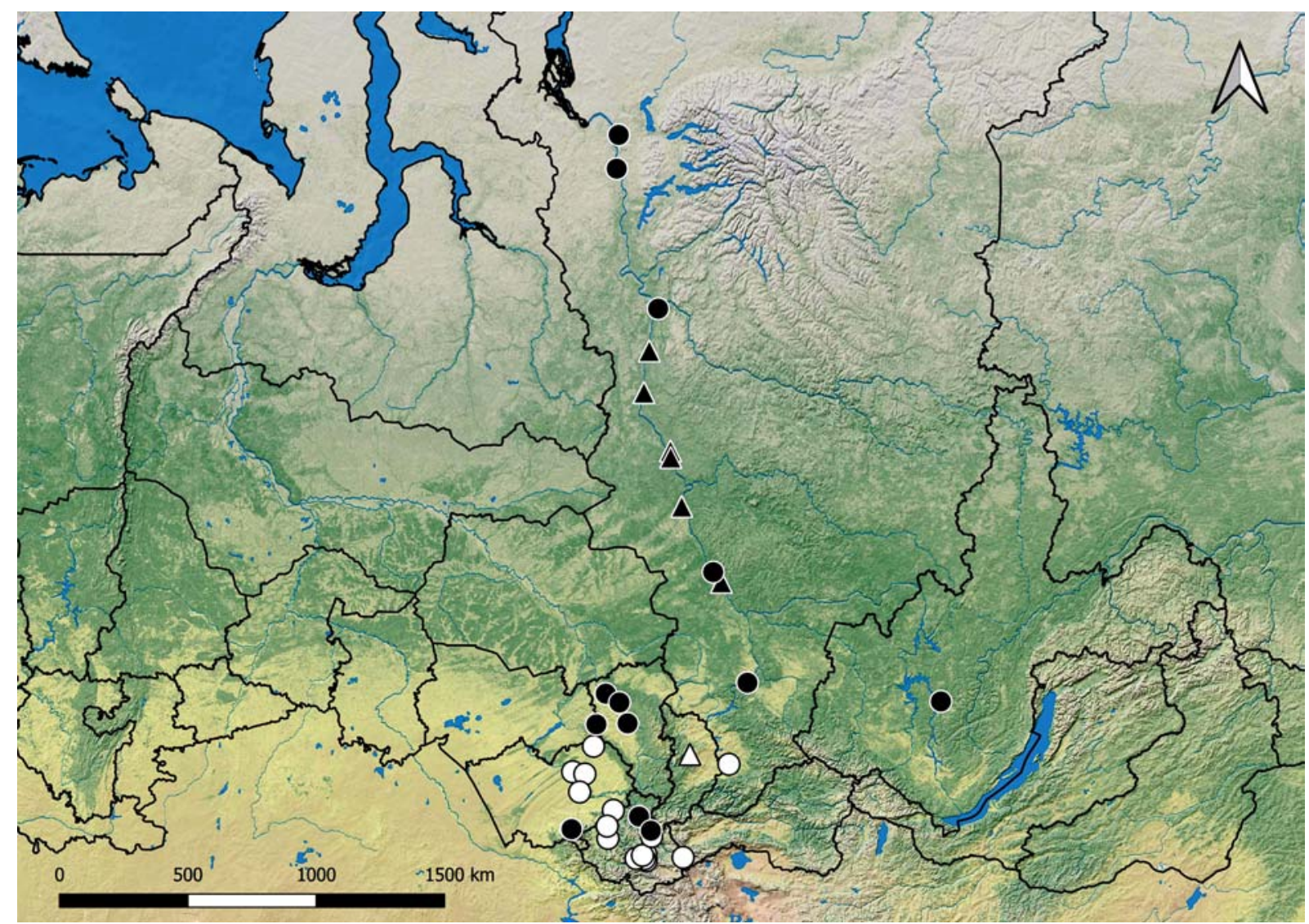

Fig. 2. Distributions of Lithobius (Ezembius) ostiacorum Stuxberg, 1876 (circle) and L. (Monotarsobius) worogowensis Eason, 1976 (triangle) in Siberia. Previously known localities marked in black, new records given in white.

Рис. 2. Распространение Lithobius (Ezembius) ostiacorum Stuxberg, 1876 (круг) и L. (Monotarsobius) worogowensis Eason, 1976 (треугольник) в Сибири. Черным отмечены ранее известные места находок, новые находки отмечены белым.

DISTRIBUTION. Originally described by Sseliwanoff [1881a, b] from the Zavkhan Province in western Mongolia, this species was later reported from the Issyk-Kul and Ala Archa regions, both Kyrgyzstan [Lignau, 1929; Dobroruka, 1979], the Inner Mongolia Autonomous Region, northern China [Verhoeff, 1934], and almost entire Mongolia [Dobroruka, 1960, 1970; Loksa, 1965, 1978; Poloczek et al., 2016; Dyachkov, 2017a]. All previous records of L. (E.) giganteus from Russia are confined to the Republic of Buryatia, eastern Siberia [Zalesskaja, 1973, 1978] and the Borgoi, Gusinooziorsk and Ivolginsk steppes in the same region [Alekseeva, 1974].

REMARKS. This species is being recorded herewith in western Siberia, namely the Republic of Altai, for the first time.

\section{Lithobius (Ezembius) ostiacorum Stuxberg, 1876 Map 2.} 308

Lithobius ostiacorum Stuxberg, 1876a: 15, 16: fig.; 1876b:

Lithobius ostiacorum - Sseliwanoff, 1881a: 12, inset: fig; Eason, 1976: 92, 94-95: figs; Zalesskaja: 1978: 125, figs; Nefediev, Aripov, 2013: 40.

Ezembius ostiacorum - Chamberlin, 1919: 19; 1923: 241.

Lithobius (Ezembius) ostiacorum - Nefediev et al., 2017a: 218: map; 2017b: 13; 2018: 229; Nefediev et al., 2020: 37, 38 map.
MATERIAL EXAMINED. 2 오 (ASU), Russia, Republic of Altai, Ulagan District, 15 air-km NNW of Aktash, near Lake Taldukiol, $50.442475^{\circ} \mathrm{N}, 87.546728^{\circ} \mathrm{E}$, sparse Larix sibirica forest, $1855 \mathrm{~m}$ a.s.l., in litter and under tree trunks and bark, 17.VII.2006; 1 juv. (ASU), near s.1., $50.443294^{\circ} \mathrm{N}, 87.534489^{\circ} \mathrm{E}$, sparse Larix sibirica forest with Betula rotundifolia, ca $1840 \mathrm{~m}$ a.s.1., in litter and moss, 18.VII.2006; 1 \% (ASU), same Republic and District, 5.5 air-km SE of Aktash, Starye Miony, near Kara-Tyt Spring, floodplain of Mionka River, $50.281032^{\circ} \mathrm{N}, 87.680762^{\circ} \mathrm{E}$, Picea obovata forest with green mosses, $1410 \mathrm{~m}$ a.s.1., 20.VII.2006; 1 ㅇ (ASU), same Republic, Kosh-Agach District, Altai State Nature Reserve, $9 \mathrm{~km} \mathrm{~S}$ of Lake Dzhulukul, near Pak-Yyash Lakes, $50.392545^{\circ} \mathrm{N}, 89.685769^{\circ} \mathrm{E}$, Betula rotundifolia, ca $2380 \mathrm{~m}$ a.s.l., in moss, 27.VII.2006; 1 o , 1 ㅇ (PSU-1240), 1 ㅇ (ASU), same Republic, Ulagan District, ca 21 air-km N of Aktash, Ulagan Pass, $50.501562^{\circ} \mathrm{N}, 87.655555^{\circ} \mathrm{E}$, sparse Pinus sibirica forest with Betula rotundifolia, in moss, ca $2065 \mathrm{~m}$ a.s.1., 31.VII.2006; $1 \mathrm{O}^{7}$ (ASU), same Republic and District, ca 3.7 air-km N of Aktash, summit of Mt Aktash, Pinus sibirica and Larix sibirica forest, $50.349499^{\circ} \mathrm{N}, 87.585986^{\circ} \mathrm{E}, 2110 \mathrm{~m}$ a.s.1., 5.VIII.2006; 2 ㅇ (ASU), same Republic, Ongudai District, 6.5 air-km ESE of Belyi Bom, valley of Tutugoi River, $50.360284^{\circ} \mathrm{N}, 87.128623^{\circ} \mathrm{E}$, Betula pendula forest, $1200 \mathrm{~m}$ a.s.1., 9.VIII.2006; 1 + (ASU), same Republic, Ulagan District, ca 18 air-km NNW of Aktash, NE part of Lake Sorulukiol, $50.463823^{\circ} \mathrm{N}, 87.485185^{\circ} \mathrm{E}$, Pinus sibirica forest with Larix sibirica, Vaccinium vitis-idaea, green mosses, $1890 \mathrm{~m}$ a.s.1., 13.VIII.2007; 1 O7, 1 juv. (ASU), same Republic, Maima District, Gorno-Altaisk, floodplain of Maima River, foot of Mt Tugaya, $51.995684^{\circ} \mathrm{N}, 85.902017^{\circ} \mathrm{E}$, Betula pendula and Acer negundo, ca 275 m a.s.1., 9.X.2014; 2 juv. (ASU), same Republic, Ongudai 
District, Seminskii Pass, $51.047968^{\circ} \mathrm{N}, 85.607156^{\circ} \mathrm{E}$, sparse Pinus sibirica forest, $1700 \mathrm{~m}$ a.s.1., 6.VII.2016, all leg. P.N., J.N.; $3 \mathrm{O}^{7} \mathrm{O}^{7}$, 1 (ASU), same Republic, Shebalino District, ca $10 \mathrm{~km} \mathrm{~S}$ of Cherga on Chuya Tract, Betula pendula and Larix sibirica forest, p.t., 21.VII.2006, leg. M.S.; 1 juv. (ASU), same Republic, Ulagan District, Altai State Nature Reserve, Stone Mushrooms (= Akkurum), $51^{\circ} 06^{\prime} 40^{\prime \prime} \mathrm{N}, 87^{\circ} 58^{\prime} 33^{\prime \prime} \mathrm{E}$, Betula pendula patch between two groups of rocks, $730 \mathrm{~m}$ a.s.l., 5.VII.2016, leg. P.N., J.N.; 19 (ASU), Russia, Altai Province, Barnaul, Yuzhnyi, mixed forest, 27.VI.2010; 24 O $^{7} \sigma^{7}, 2$ 우 (PSU-1281), 4 우 (ASU), same Province, Kosikha District, near Ozero-Krasilovo, ASU Field Station, Lake Krasilovo, Pinus sylvestris, Betula pendula and Populus tremula forest with tall grass vegetation, p.t., 30.VI.-5.VII.2014; 11 $\sigma^{7} \sigma^{7}, 5$ 우 (PSU-1273), s.l., p.t., 5-10.VII.2014; 2 우, 1 subadult $\sigma^{7}$ (ASU), same Republic, Zalesovo District, near Peshchiorka, $54^{\circ} 05^{\prime} 00^{\prime \prime} \mathrm{N}, 84^{\circ} 49^{\prime} 31^{\prime \prime} \mathrm{E}$, Populus tremula forest with Betula pendula and Salix, $240 \mathrm{~m}$ a.s.1. 9.IX.2015, all leg. P.N.; 6 O $^{7} \mathrm{O}^{7}, 5$ OP㇒, 2 subadult 우 (ASU), same Province, Troitskoye District, near Chervyanka, young Pinus sylvestris forest, p.t., 17-27.VI.2016; $10^{7}, 1$ \% (PSU-1267), s.1., p.t., 15-24.VIII.2016, 2 우, 1 juv. (ASU), near s.1., Pinus sylvestris forest, p.t., 16-25.VIII.2016, all leg. N.V.; 1 $\sigma^{T}$ (PSU-819), Russia, Krasnoyarsk Province, Minusinsk Dis-

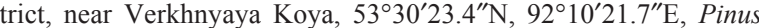
sylvestris forest, ca $400 \mathrm{~m}$ a.s.1., 3.IX.2007, leg. S.D.

DISTRIBUTION. This species was originally described by Stuxberg [1876a, b] from the Yenisei River region, Krasnoyarsk Province, central Siberia, and redescribed a century later by Eason [1976] from Stuxberg's type material. All subsequent records expanded its distribution area in Asian Russia to the Irkutsk Area [Zalesskaja, 1978], the Altai Province [Zalesskaja, 1978; Nefediev et al., 2017b, 2018], the Republic of Altai [Nefediev et al., 2017a], and the Kemerovo Area [Nefediev et al., 2020]. This species is also known from northern Mongolia [Poloczek et al., 2016].

REMARKS. The above records extend the distribution area of $L$. (E.) ostiacorum to the central and southeastern parts of the Republic of Altai, northeastern and central parts of the Altai Province, as well as to the southern part of the Krasnoyarsk Province.

\section{Lithobius (Ezembius) princeps Stuxberg, 1876 Map 1.}

Lithobius princeps Stuxberg, 1876a: 17, 18: fig; 1876b: 309. Lithobius scrobiculatus Stuxberg, 1876a: 19; 1876b: 310; Eason, 1976: 100, 101: fig.

Monotarsobius princeps - Attems, 1909: 18.

Ezembius princeps — Chamberlin, 1919: 19; 1923: 241

Ezembius scrobiculatus — Chamberlin, 1919: 19; 1923: 241.

Lithobius princeps — Eason, 1976: 97, 98-99: figs; Zalesskaja, 1978: 121, 122: figs; Nefediev, Aripov, 2013: 40.

Lithobius (Ezembius) princeps - Sergeeva, 2010: 38; Bukhkalo et al., 2014: 72; Nefediev et al., 2017c: 116, 117: map.

? Lithobius Czekanowskii - Sseliwanoff, 1881a: inset: fig; 1881b: 15 .

MATERIAL EXAMINED. $9 \sigma^{7} \sigma^{7}, 1$ + (PSU-823), Russia, Republic of Khakassia, Altai District, Ochurskii Bor, $53^{\circ} 09^{\prime} 33$. $5^{\prime \prime N}, 9^{\circ} 36^{\prime} 35.9^{\prime \prime}$ E, Pinus sylvestris forest, 30.IX.2008, leg. D.P.

DISTRIBUTION. Originally described by Stuxberg [1876a, b] from near the Podkamennaya Tunguska River in the Yenisei River region, Krasnoyarsk Province, central Siberia, this species was redescribed by Eason [1976] from Stuxberg's type material, with lectotype designation. It was later recorded from Eastern Kazakhstan [Tuf, 2007; Tuf et al., 2010; Dyachkov, 2017b, 2019], the Tyumen and Omsk areas, both southwestern Siberia [Sergeeva, 2010; Bukhkalo et al., 2014; Nefediev et al., 2017c].

REMARKS. The above records of this species are new to the Republic of Khakassia.

\section{Lithobius (Ezembius) proximus Sseliwanoff, 1880 Map 3.}

Lithobius proximus Sseliwanoff, 1880b: 23.

Lithobius proximus - Sseliwanoff, 1881a: 10, inset: fig; Alekseeva, 1974: 8; Zalesskaja, 1978: 125, figs; Vorobiova, 1999: 33; Rybalov, 2002: 81; Vorobiova et al., 2002: 61; Striganova, Poryadina, 2005: 226; Sergeeva, 2010: 37; Bukhkalo, Sergeeva, 2012: 61.

Lithobius (Ezembius) proximus - Sergeeva, 2010: 38; 2013: 530; Bukhkalo et al., 2014: 71; Dyachkov, 2017b: 454; Nefediev et al., 2017a: 218, map; 2017b: 13; 2017c: 116, 117: map; 2018: 230; 2020: 38, map.

MATERIAL EXAMINED. 1 juv. (ASU), Russia, Republic of Altai, Ulagan District, near Aktash, N slope of Mt Belkenek behind Mionka River, $50.305420^{\circ} \mathrm{N}, 87.589075^{\circ} \mathrm{E}$, Picea obovata forest with Pinus sibirica and Larix sibirica, $1345 \mathrm{~m}$ a.s.l., in litter, 16.VII.2006; 2 juv. (ASU), same Republic, Ongudai District, 9 air$\mathrm{km}$ SSW of Belyi Bom, near Achik Pass, $50.295678^{\circ} \mathrm{N}, 86$. $977943^{\circ} \mathrm{E}$, sparse Pinus sibirica forest edge, $2120 \mathrm{~m}$ a.s.1., 21.VII. 2006, all leg. P.N., J.N.; 1 ○ (PSU-1019), 8 juv. (ASU), same Republic, Shebalino District, 3.5 air-km SE of Topuchaya, 51. $11235^{\circ} \mathrm{N}, 85.63166^{\circ} \mathrm{E}$, mixed herbaceous meadow, ca $1435 \mathrm{~m}$ a.s.1., p.t., 20-22.VII.2018, leg. P.N.; $2 \sigma^{\top} \sigma^{\top}, 2$ 90,8 juv. (PSU1020), 6 우, 5 juv. (ASU), near s.1., $51.11189^{\circ} \mathrm{N}, 85.63219^{\circ} \mathrm{E}$, Betula pendula, Larix sibirica, Pinus sibirica and Picea obovata forest with Alnus, Lonicera, Ribes nigrum and tall grass vegetation on hummocks, along brook, ca $1435 \mathrm{~m}$ a.s.1., b.h., sifted leaf litter, p.t., 20-22.VII.2018, leg. P.N., V.G., M.M., V.L.; 2 juv. (ASU), same Republic, Ongudai District, ca 6.25 air-km NEE of Seminskii Pass, Seminskii Mt. Range, near Mt Sarlyk, $51^{\circ} 03.558^{\prime} \mathrm{N}, 85^{\circ}$ $41.452^{\prime} \mathrm{E}$, alpine meadow with scattered Pinus sibirica and Picea obovata trees, ca $2055 \mathrm{~m}$ a.s.l., sifting leaf litter under trees over 100 m, 21.VII.2018, leg. V.G., M.M., V.L.; 2 juv. (ASU), same Republic and District, ca 7.5 air-km NEE of Seminskii Pass, Seminskii Mt. Range, near Mt Sarlyk, $51^{\circ} 03.754^{\prime} \mathrm{N}, 85^{\circ} 42.523^{\prime} \mathrm{E}$, alpine meadow with sparse Larix sibirica, under stones, $1970 \mathrm{~m}$ a.s.1., 21.VII.2018, leg. P.N., V.G.; 3 juv. (ASU), near s.1., $51^{\circ} 03$. $737^{\prime} \mathrm{N}, 85^{\circ} 42.492^{\prime} \mathrm{E}$, alpine meadow belt, patches of Betula rotundifolia, Salix, dwarf Juniperus, scattered Picea obovata and Larix sibirica trees, ca $1955 \mathrm{~m}$ a.s.1., sifting leaf litter and moss over 80 m, 21.VII.2018; 1 juv. (ASU), same Republic and District, 8 air$\mathrm{km}$ NEE of Seminskii Pass, Seminskii Mt. Range, $51^{\circ} 04.031^{\prime} \mathrm{N}$, $85^{\circ} 42.779^{\prime} \mathrm{E}$, alpine meadow with bush patches of Betula rotundifolia and Salix, and few scattered trees of Pinus sibirica, Picea obovata and Larix sibirica, ca $2065 \mathrm{~m}$ a.s.1., sifting leaf litter and moss over 70 m, 21.VII.2018, all leg. V.G., M.M., V.L.; 1 + 1 juv. (PSU-1029), same Republic and District, 10.5 air-km NE of Seminskii Pass, Seminskii Mt. Range, foot of Mt Sarlyk, Lakes Tuyukskiye, $51^{\circ} 04.547^{\prime} \mathrm{N}, 85^{\circ} 44.560^{\prime} \mathrm{E}$, mountain tundra, under stones, ca $2230 \mathrm{~m}$ a.s.1., 21.VII.2018, leg. P.N.; 1 (ASU), same Republic and District, 20 air-km W of Chibit, valley of Chuya River, environs of Shirlak Waterfall, $50^{\circ} 20.670^{\prime} \mathrm{N}, 87^{\circ} 13.388^{\prime} \mathrm{E}$, riverine terrasse and slopes with Picea obovata, Betula pendula and Caragana arborescens, $1000 \mathrm{~m}$ a.s.l., sifting flood refuse and leaf litter at river banks and on slopes over $300 \mathrm{~m}, 23$.VII.2018, leg. V.G., M.M., V.L.; 1 O$^{7}, 1$ ㅇ, 1 juv. (PSU-1002), same Republic, Ulagan District, 10 air-km ENE of Aktash, Kurai Mt. Range, summit with retranslator, $50.33958^{\circ} \mathrm{N}, 87.74865^{\circ} \mathrm{E}$, rocky mountain tundra, ca $2970 \mathrm{~m}$ a.s.1., under stones, 23.VII.2018, leg. P.N., V.G., M.M., V.L.; 3 juv. (ASU), near s.l., near summit with retranslator, $50.32598^{\circ} \mathrm{N}, 87.73575^{\circ} \mathrm{E}$, alpine meadow with rich herbaceous vegetation, Poaceae, Dryas, moss and lichens, ca $2570 \mathrm{~m}$ a.s.1., under stones, 23.VII.2018; 1 juv. (ASU), same Republic and District, 3 air-km NE of Aktash, valley of Yarlyamry River, $50.33350^{\circ} \mathrm{N}$, $87.64925^{\circ} \mathrm{E}$, Picea obovata taiga forest with Larix sibirica, Caragana arborescens and Alnus, $1575 \mathrm{~m}$ a.s.1., in green mosses, 24.VII.2018, all leg. P.N.; 1 ऽ, 3 juv. (ASU), same Republic and District, 3.5 air-km NE of Aktash, valley of Yarlyamry River, $50^{\circ}$ $20.027^{\prime} \mathrm{N}, 87^{\circ} 38.945^{\prime} \mathrm{E}$, forest with Picea obovata, Larix sibirica, Pinus sibirica, Caragana arborescens, Lonicera, Ribes nigrum, moss, $1575 \mathrm{~m}$ a.s.1., sifting leaf litter and moss over $50 \mathrm{~m}, 24$.VII. 


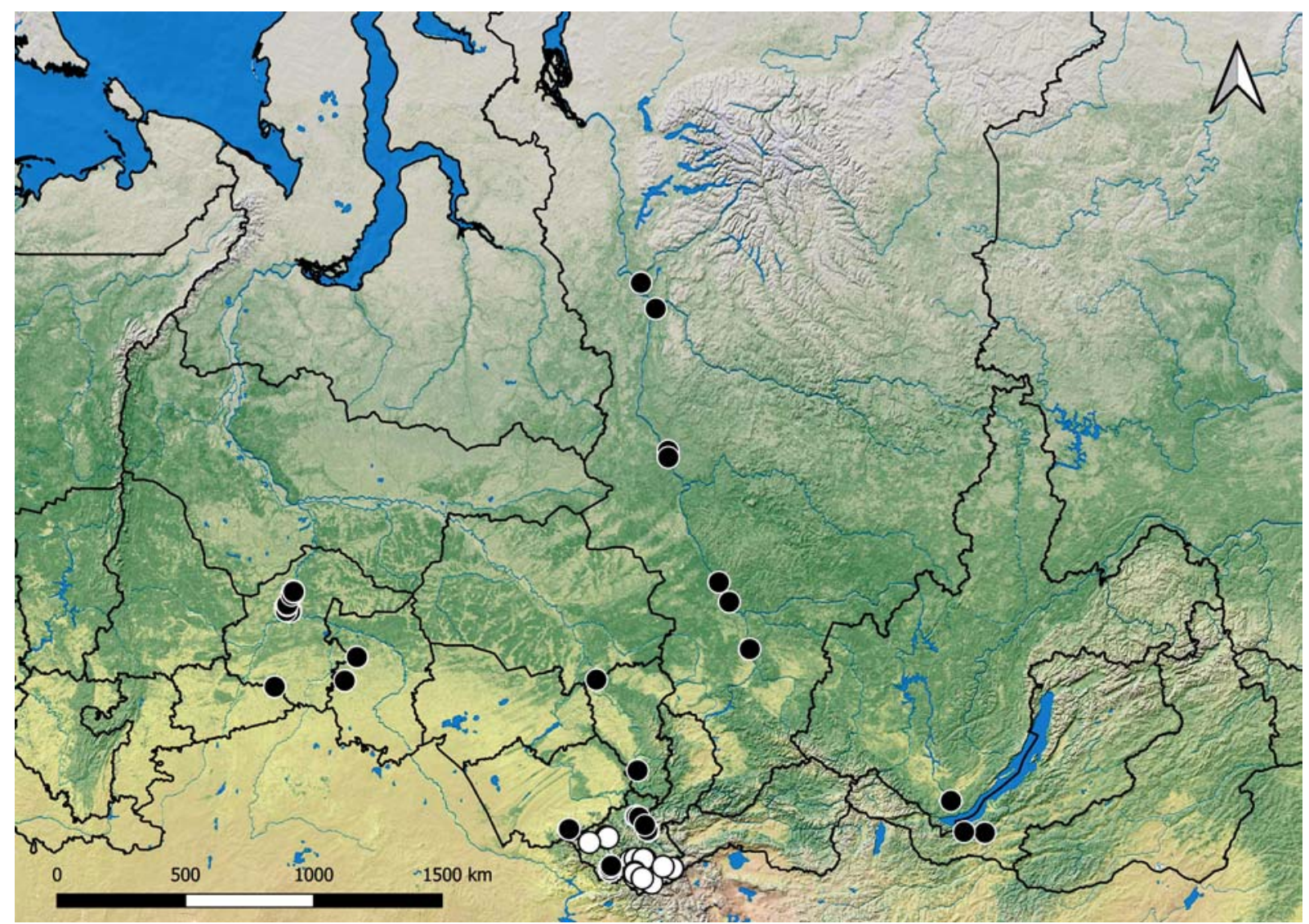

Fig. 3. Distribution of Lithobius (Ezembius) proximus Sseliwanoff, 1880 in Siberia. Previously known localities marked in black, new records given in white.

Рис. 3. Распространение Lithobius (Ezembius) proximus Sseliwanoff, 1880 в Сибири. Черным отмечены ранее известные места находок, новые находки отмечены белым.

2018, leg. V.G., M.M., V.L.; $2 \sigma^{\top} \sigma^{\top}, 2$ 우, 2 juv. (PSU-1004), same Republic and District, 4 air-km NE of Aktash, valley of Yarlyamry River, $50^{\circ} 19.912^{\prime} \mathrm{N}, 87^{\circ} 39.539^{\prime} \mathrm{E}$, forest with Picea obovata, Pinus sibirica, Larix sibirica, Vaccinium vitis-idaea, Equisetum, Lonicera, ca $1640 \mathrm{~m}$ a.s.1., sifting leaf litter and moss over 50 m, 24.VII.2018, leg. V.G., M.M., V.L.; $1 \sigma^{\top}, 2$, 9 , 1 juv. (ASU), same Republic, Kosh-Agach District, 20 air-km NE of Kokorya, Chikhachiova Mt. Range, Talduair massif, right bank of Sailyugem River, $50.01802^{\circ} \mathrm{N}, 89.23557^{\circ} \mathrm{E}$, floodplain Larix sibirica forest, $2225 \mathrm{~m}$ a.s.1., under stones, 26.VII.2018, leg. P.N., M.M., V.L.; 1 ㅇ, 6 juv. (ASU), near s.1., bottom of S slope, $50.01770^{\circ} \mathrm{N}$, $89.23775^{\circ} \mathrm{E}$, scree with Astragalus, Artemisia, Comarum salesovianum, ca $2245 \mathrm{~m}$ a.s.l., under stones lying on bush branches, in herb debris, 26.VII.2018; 1 क (ASU), near s.1., $50.01570^{\circ} \mathrm{N}$, $89.25483^{\circ} \mathrm{E}$, rocky tundra on S slope, ca $2485-2500 \mathrm{~m}$ a.s.l., under stones, 26.VII.2018; $1 \mathrm{O}^{\top}$ (ASU), near s.1., $50.01550^{\circ} \mathrm{N}, 89.25079^{\circ} \mathrm{E}$, subalpine meadow, ca $2425 \mathrm{~m}$ a.s.1., under stones, 26.VII.2018, all leg. P.N.; 2 juv. (ASU), near s.1., $50^{\circ} 01.078^{\prime} \mathrm{N}, 8^{\circ} 14.136^{\prime} \mathrm{E}$, meadow, ca $2215 \mathrm{~m}$ a.s.1., sifting grass tussocks and moss over $80 \mathrm{~m}$, 26.VII.2018; 2 juv. (ASU), near s.1., $50^{\circ} 01.078^{\prime} \mathrm{N}, 8^{\circ} 14.136^{\prime} \mathrm{E}$, Larix sibirica forest patch, ca $2215 \mathrm{~m}$ a.s.l., sifting leaf litter over 40 m, 26.VII.2018; 1 q, 1 juv. (ASU), near s.1., left bank of Sailyugem River, $50^{\circ} 01.044^{\prime} \mathrm{N}, 89^{\circ} 14.117^{\prime} \mathrm{E}$, forest, riverine and on NE-facing slopes, Larix sibirica, Lonicera, few Pinus, $2215 \mathrm{~m}$ a.s.1., sifting leaf litter and moss over $80 \mathrm{~m}$, 26.VII.2018, all leg. V.G., M.M., V.L.; 2 juv. (ASU), same Republic and District, 47 air-km ESE of Belyashi (=Dzhazator), valley of Zhumaly River, $49.51326^{\circ} \mathrm{N}, 88.01883^{\circ} \mathrm{E}$, Betula rotundifolia thicket, $2340 \mathrm{~m}$ a.s.1., in moss, under stones, 27.VII.2018; 6 juv. (ASU), near s.1., 49. $51252^{\circ} \mathrm{N}, 88.01705^{\circ} \mathrm{E}$, rocky plateau with Dryas patches on E slope, $2415 \mathrm{~m}$ a.s.1., under stones, 27.VII.2018, all leg. P.N.; 1 juv. (ASU), near s.1., $49^{\circ} 30.020^{\prime} \mathrm{N}, 88^{\circ} 07.328^{\prime} \mathrm{E}$, bottom of small ravine, $2590 \mathrm{~m}$ a.s.1., sifting soil next to snow patch, dead grass, and leaf litter and moss under Betula rotundifolia patches over $20 \mathrm{~m}$, 27.VII.2018, leg. V.G., M.M., V.L.; 3 juv. (ASU), same Republic and District, 14 air-km W of Belyashi (=Dzhazator), valley of Koksu River, left bank, $49.70599^{\circ} \mathrm{N}, 87.21581^{\circ} \mathrm{E}$, Picea obovata forest with Caragana arborescens, Vaccinium vitis-idaea and green moss, ca $1605 \mathrm{~m}$ a.s.1., 28.VII.2018; 1 juv. (ASU), near s.1., cliff edge on left bank of Koksu River, $49.71032^{\circ} \mathrm{N}, 87.22144^{\circ} \mathrm{E}$, mixed forest with Larix sibirica, Pinus sibirica, Betula pendula and Populus tremula with Bergenia crassifolia and low grasses on rocks, $1670 \mathrm{~m}$ a.s.1., under stones, 28.VII.2018, all leg. P.N.; 1 juv. (ASU), near s.1., $49^{\circ} 42.369^{\prime} \mathrm{N}, 87^{\circ} 12.943^{\prime} \mathrm{E}$, forest with Picea obovata and Larix sibirica, ca $1610 \mathrm{~m}$ a.s.1., sifting leaf litter and moss over 200 m, 28.VII.2018, leg. V.G., M.M., V.L.; 1 ๑ , 4 +क (PSU1003), same Republic and District, 26 air-km NNW of Belyashi (=Dzhazator), valley of Karagem River, floodplain, $49.88593^{\circ} \mathrm{N}$, $87.19024^{\circ} \mathrm{E}$, riverine Populus forest with Larix sibirica, ca $1355 \mathrm{~m}$ a.s.1., in litter, 29.VII.2018; 3 juv. (ASU), near s.1., W macroslope of Yuzhno-Chuiskii Mt. Range, $49.88531^{\circ} \mathrm{N}, 87.19548^{\circ} \mathrm{E}$, moraines on left bank of Karagem River, Larix sibirica forest with Caragana arborescens, ca $1385 \mathrm{~m}$ a.s.l., in litter and in moss, 29. VII.2018; 1 ㅇ (ASU), near s.1., $49.88080^{\circ} \mathrm{N}, 87.20740^{\circ} \mathrm{E}$, Larix sibirica forest on W slope in brook valley, ca $1590 \mathrm{~m}$ a.s.1., in moss, 29.VII.2018; 1 (ASU), same Republic and District, 21 airkm NW of Belyashi (=Dzhazator), S macroslope of Yuzhno-Chuiskii Mt. Range, ford on Karasu River, $49.83549^{\circ} \mathrm{N}, 87.20798^{\circ} \mathrm{E}$, Pinus sibirica and Picea obovata forest with Betula pendula, Alnus, Caragana, Ribes nigrum, small grass vegetation and green mosses, 


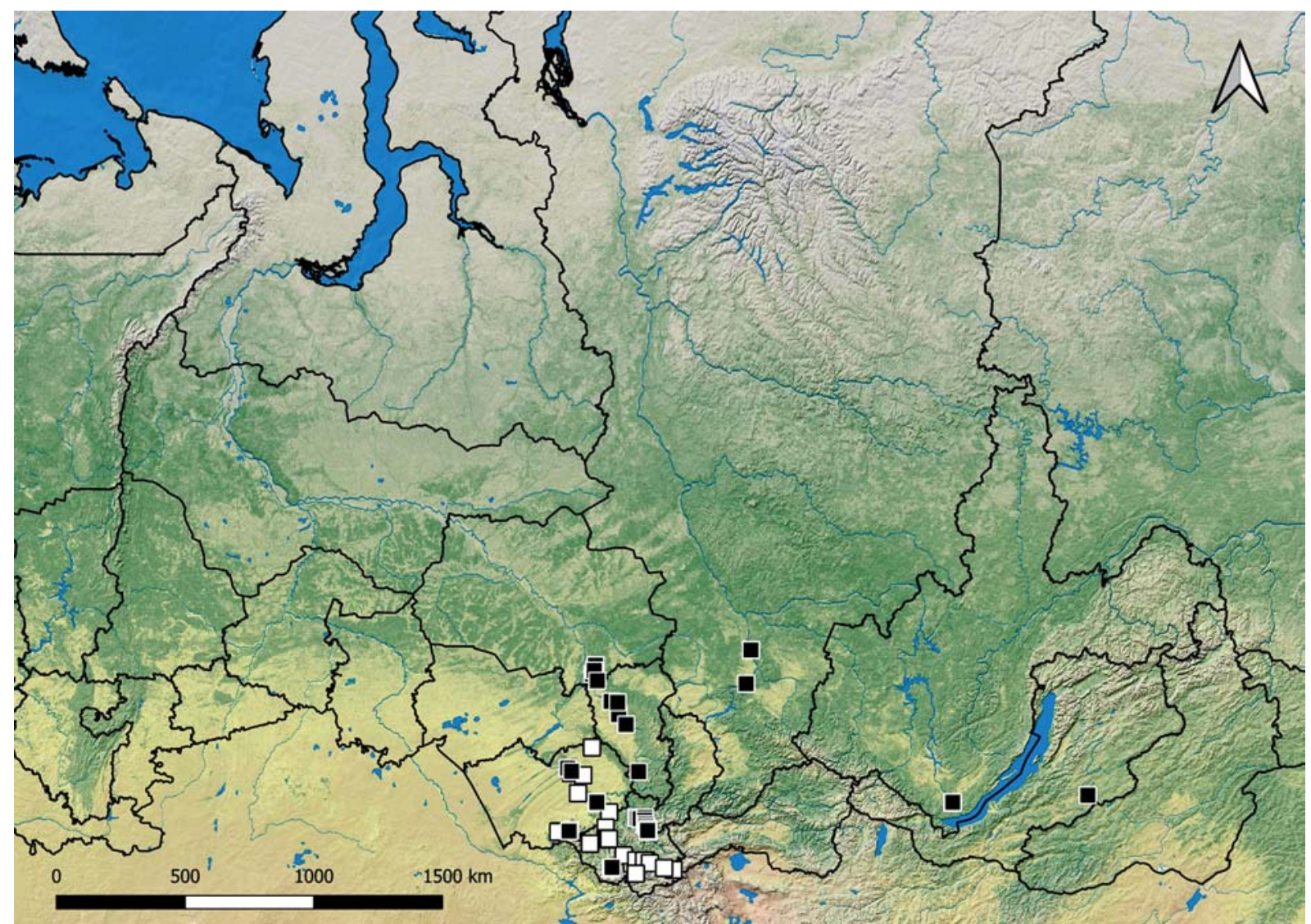

Fig. 4. Distribution of Lithobius (Ezembius) sibiricus Gerstfeldt, 1859 in Siberia. Previously known localities marked in black, new records given in white.

Рис. 4. Распространение Lithobius (Ezembius) sibiricus Gerstfeldt, 1859 в Сибири. Черным отмечены ранее известные места находок, новые находки отмечены белым.

ca $1605 \mathrm{~m}$ a.s.1., 29.VII.2018, all leg. P.N.; $1 \sigma^{7}, 1$ juv. (ASU), near s.1., $49^{\circ} 50.122^{\prime} \mathrm{N}, 87^{\circ} 12.493^{\prime} \mathrm{E}$, forest with Pinus sibirica and Larix sibirica, large trees, $1590 \mathrm{~m}$ a.s.l., sifting leaf litter and moss over 50 m, 29.VII.2018, leg. V.G., M.M., V.L.; 1 juv. (ASU), same Republic and District, 12 air-km ESE of Belyashi (=Dzhazator), $49.67064^{\circ} \mathrm{N}, 87.59399^{\circ} \mathrm{E}$, Picea obovata and Larix sibirica forest, ca $1635 \mathrm{~m}$ a.s.1., under stones and in litter, 30.VII.2018; 7 juv. (ASU), same Republic and District, 13.5 air-km ESE of Belyashi (=Dzhazator), valley of Uzurgu River (=Tenektybulak/Terektybulak River), $49.66981^{\circ} \mathrm{N}, 87.60945^{\circ} \mathrm{E}$, Larix sibirica and Picea obovata forest with Pinus sibirica, ca $1635 \mathrm{~m}$ a.s.1., under stones, 30.VII.2018; 2 O+, 12 juv. (ASU), same Republic and District, 8 air-km NNE of Kosh-Agach, Kurai Mt. Range, valley of Tabozhok River, foot of NW slope of Mt Tabozhok, $50.07596^{\circ} \mathrm{N}, 88.72931^{\circ} \mathrm{E}$ Larix sibirica forest with Alnus, ca $2065 \mathrm{~m}$ a.s.1., under stones, all leg. P.N.; near s.1., $50^{\circ} 04.607^{\prime} \mathrm{N}, 88^{\circ} 43.745^{\prime} \mathrm{E}$, dry ravine with spring surrounded by bushes, ca $2050 \mathrm{~m}$ a.s.l., sifting litter, dead grass and moss near spring over $200 \mathrm{~m}, 31 . \mathrm{VII} .2018$, leg. V.G. M.M., V.L.; 2 juv. (ASU), same Republic, Ust-Kan District, 2 air$\mathrm{km}$ SW of Ust-Kan, valley of Kutergen River, $50.90546^{\circ} \mathrm{N}, 84$ $73464^{\circ}$ E, Picea obovata forest with Spiraea and green mosses on left river bank, ca $1180 \mathrm{~m}$ a.s.l., in and under moss, covering big stones, 19.VIII.2018, leg. P.N

DISTRIBUTION. Being originally described by Sseliwanoff [1880b] from Irkutsk, central Siberia, this species is widely distributed in European Russia [Zalesskaja, 1978], Ukraine [Chornyi, Kosyanenko, 2003], and the Urals [Farzalieva, Esyunin, 2008], as well as in Eastern Kazakhstan [Tuf, 2007; Tuf et al., 2010; Dyachkov, 2017b, 2019]. In Asian Russia, L. (E.) proximus has previously been known from the Republic of Buryatia [Alekseeva, 1974], the Altai Province [Zalesskaja, 1978; Nefediev et al., 2018], the Tyumen Area [Striganova, Poryadina, 2005; Sergeeva, 2010, 2013; Bukhkalo, Sergeeva, 2012; Bukhkalo et al., 2014], the Krasnoyarsk Province [Vorobiova, 1999; Rybalov, 2002; Vorobiova et al., 2002], the Republic of Altai [Nefediev et al., 2017], the Kemerovo Area [Nefediev et al., 2020], the Maritime Province and the Sakhalin Area [Molodova, 1972; Kurcheva, 1977]. Lithobius (E.) proximus has recently reported in the Wigry National Park, Poland [Wytwer, Tajovský, 2019], this representing the westernmost record of the species.

REMARKS. According to the literature data, in the Republic of Altai, this species has previously been reported only from the NE part of this area (i.e. the environs of Lake Teletskoye), whilst the new records expand its distribution area to the whole territory of the Republic.

Lithobius (Ezembius) sibiricus Gerstfeldt, 1859 Map 4.

Lithobius sibiricus Gerstfeldt, 1859: 275

Lithobius affinis Sseliwanoff, 1880b: 20

Lithobius sibiricus — Sseliwanoff, 1880a: 542; 1881a: 5, inset: fig; Alekseeva, 1974: 8; Eason, 1976: 115, 116: figs; Zalesskaja, 1978: 124, figs; Vorobiova, 1999: 33; Nefediev, 2001: 85; Vorobiova et al., 2002: 61; Nefediev, Aripov, 2013: 40.

Monotarsobius sibiricus - Attems, 1909: 18. 
Lithobius (Ezembius) sibiricus — Nefediev et al., 2016: 263 264: map; 2017a: 219, 218: map; 2017b: 13; 2017c: 118; 2020: 39, map; Dyachkov, 2017b: 454.

non Lithobius sibiricus - Haase, 1880: 223.

MATERIAL EXAMINED. 1 \%, 1 \% (ASU), Russia, Altai Province, Barnaul, Yuzhnyi, mixed forest, 27.VI.2010; $2 \sigma^{\top} \sigma^{\top}, 1$ +, 1 juv. (ASU), same Province, Altaiskoye District, ca 5 air-km NW of Aya, Lake Aichionok, Betula pendula patch on bank, in litter, 6.VII.2010, all leg. P.N.; 1 (ASU), same Province, Troitskoye District, near Chervyanka, young Pinus sylvestris forest, p.t., 1524.VIII.2016, leg. N.V.; $12 \bigcirc^{7} \sigma^{7}, 13$ qo, 1 juv. (PSU-1280), same Province, Kosikha District, near Ozero-Krasilovo, ASU Field Station, Lake Krasilovo, Pinus sylvestris, Betula pendula and Populus tremula forest with tall grass vegetation, p.t., 30.VI.-5.VII.2014; 7 $\sigma^{7} \sigma^{7}, 1$ (PSU-1274), s.1., p.t., 5-10.VII.2014, all leg. P.N.; 1 ㅇ, 1 juv. (ASU), same Province, Krasnoshchiokovo District, near Chineta, Chineta Nature Reserve, floodplain of Inya River, near bridge on left bank, $51^{\circ} 20^{\prime} 20.2^{\prime \prime} \mathrm{N}, 83^{\circ} 02^{\prime} 16.0^{\prime \prime} \mathrm{E}$, Salix with Caragana arborescens and Lonicera tatarica, $365 \mathrm{~m}$ a.s.1., litter, 6.VI.2015; 2 juv. (ASU), same Province and District, near Chineta, Chineta Nature Reserve, $51^{\circ} 19^{\prime} \mathrm{N}, 83^{\circ} 00^{\prime} \mathrm{E}$, Betula pendula, Pinus sylvestris, Populus tremula with Caragana arborescens and Lonicera tatarica, on slope of hill, $480 \mathrm{~m}$ a.s.1., litter, 6.VI.2015, all leg. P.N., J.N.; 1 juv. (ASU), same Republic, Zalesovo District, near Peshchiorka, 54 $05^{\prime} 00^{\prime \prime} \mathrm{N}, 84^{\circ} 49^{\prime} 31^{\prime \prime} \mathrm{E}$, Populus tremula forest with Betula pendula and Salix, $240 \mathrm{~m}$ a.s.1. 9.IX.2015, leg. P.N.; 1 \% (ASU), Russia, Republic of Altai, Ulagan District, near Aktash, N slope of Mt Belkenek behind Mionka River, $50.305420^{\circ} \mathrm{N}$, $87.589075^{\circ} \mathrm{E}$, Picea obovata forest with Pinus sibirica and Larix sibirica, $1345 \mathrm{~m}$ a.s.1., in litter, 16.VII.2006; 1 \% (ASU), near s.1., old fire-site overgrown with young Betula pendula forest with Ribes nigrum, 2.VIII.2006; 1 ○ (PSU-1243), same Republic and District, ca 9 air-km SE of Aktash, near Mt Baratal, valley of Chuya River, Betula pendula and Picea obovata forest, $1510 \mathrm{~m}$ a.s.1., 20.VII.2006; 1 \% (PSU-1237), same Republic, Kosh-Agach District, 15.5 air-km S of Belyi Bom, $50.229991^{\circ} \mathrm{N}, 87.002996^{\circ} \mathrm{E}$, under Juniperus on cliff, $1725 \mathrm{~m}$ a.s.1., 22.VII.2006, all leg. P.N., J.N.; $1 \sigma^{7}, 2$ क् (ASU), same Republic, Shebalino District, ca 10 $\mathrm{km} \mathrm{S}$ of Cherga on Chuya Tract, Betula pendula and Larix sibirica forest, p.t., 21.VII.2006; $11 \sigma^{\top} \sigma^{7}, 11$ कo, 1 juv. (PSU-1271), same Republic, Ongudai District, Bolshoi Yaloman River, ca $2 \mathrm{~km}$ upstream from mouth, Betula pendula and Populus floodplain forest, p.t., 23.VII.2006, all leg. M.S.; $9 \sigma^{\top} \sigma^{\top}, 9$ 0 + 9 juv. (PSU-1032), same Republic, Shebalino District, 10 air-km NE of Seminski Pass, Seminskii Mt. Range, summit of Mt Sarlyk, $51^{\circ} 04.633^{\prime} \mathrm{N}$, $85^{\circ} 44.134^{\prime} \mathrm{E}$, rocky desert with patches of mountain tundra, under stones, $2505 \mathrm{~m}$ a.s.1., 21.VII.2018; 2 우 (PSU-1025), same Republic, Ongudai District, ca $4 \mathrm{~km}$ SE of Topuchaya, $51^{\circ} 05.990^{\prime} \mathrm{N}$, $85^{\circ} 37.433^{\prime} \mathrm{E}$, near spring, under logs and stones, ca $1270 \mathrm{~m}$ a.s.1., 22.VII.2018, all leg. P.N.; $3 \sigma^{7} \sigma^{7}, 5$ of, 7 juv. (PSU-1027), same Republic and District, ca 7.5 air-km NEE of Seminskii Pass, Seminskii Mt. Range, near Mt Sarlyk, $51^{\circ} 03.754^{\prime} \mathrm{N}, 85^{\circ} 42.523^{\prime} \mathrm{E}$, alpine meadow with sparse Larix sibirica, under stones, $1970 \mathrm{~m}$ a.s.1., 21.VII.2018, leg. P.N., V.G.; 1 क (PSU-1007), near s.1., 51 $03.964^{\prime} \mathrm{N}, 85^{\circ} 42.421^{\prime} \mathrm{E}$, forest patch with Pinus sibirica and Picea obovata, small gaps, rocky, Betula rotundifolia, ca $1990 \mathrm{~m}$ a.s.l., sifting leaf litter and moss over 120 m, 21.VII.2018, leg. V.G., M.M., V.L.; $4 \bigcirc^{7} \sigma^{7}, 4$ 우, 6 juv. (PSU-1028), same Republic and District, 10.5 air-km NE of Seminskii Pass, Seminskii Mt. Range, foot of Mt Sarlyk, Lakes Tuyukskiye, $51^{\circ} 04.547{ }^{\prime} \mathrm{N}, 85^{\circ} 44.560^{\prime} \mathrm{E}$, mountain tundra, under stones, ca $2230 \mathrm{~m}$ a.s.1., 21.VII.2018, leg. P.N.; $1 \sigma^{\top}$ (PSU-1023), same Republic and District, floodplain of Chuya River, near Shirlak Waterfall, $50.34461^{\circ} \mathrm{N}, 87.22323^{\circ} \mathrm{E}$, Betula pendula forest on river bank, $1015 \mathrm{~m}$ a.s.1., 23.VII.2018, leg. V.G.; $3 \bigcirc^{7} \sigma^{7}, 3$ 우, 2 juv. (ASU), near s.1., right bank of Chuya River, $50^{\circ} 20.615^{\prime} \mathrm{N}, 87^{\circ} 13.335^{\prime} \mathrm{E}$, Betula forest with Larix sibirica, Caragana arborescens, small grass vegetation and green mosses, ca $1015 \mathrm{~m}$ a.s.1., 23.VII.2018; 1 juv. (ASU), near s.1., $50^{\circ} 20$. $650^{\prime} \mathrm{N}, 87^{\circ} 13.338^{\prime} \mathrm{E}$, Betula pendula and Picea obovata forest, green mosses, ca $1035 \mathrm{~m}$ a.s.1., 23.VII.2018; 1 o', 2 우, 2 juv. (ASU), near s.1., environs of Shirlak Waterfall, along Tektu River down the waterfall, $50^{\circ} 20.725^{\prime} \mathrm{N}, 87^{\circ} 13.149^{\prime} \mathrm{E}$, Betula pendula forest with Alnus, ca 1080 m a.s.1., 23.VII.2018, all leg. P.N.; 2 juv.
(ASU), same Republic, Ulagan District, 10 air-km ENE of Aktash, Kurai Mt. Range, summit with retranslator, $50.33958^{\circ} \mathrm{N}, 87$. $74865^{\circ} \mathrm{E}$, rocky mountain tundra, ca $2970 \mathrm{~m}$ a.s.1., under stones, 23.VII.2018, leg. P.N., V.G., M.M., V.L.; 1 , 1 juv. (ASU), near s.1., near summit with retranslator, $50.32598^{\circ} \mathrm{N}, 87.73575^{\circ} \mathrm{E}$, alpine meadow with rich herbaceous vegetation, Poaceae, Dryas, moss and lichens, ca $2570 \mathrm{~m}$ a.s.1., under stones, 23.VII.2018, leg. P.N.; $1 \sigma^{7}, 1$ juv. (ASU), same Republic and District, 3.5 air-km NE of Aktash, valley of Yarlyamry River, $50^{\circ} 20.027^{\prime} \mathrm{N}, 87^{\circ} 38.945^{\prime} \mathrm{E}$, forest with Picea obovata, Larix sibirica, Pinus sibirica, Caragana arborescens, Lonicera, Ribes nigrum, moss, 1575 m a.s.l., sifting leaf litter and moss over $50 \mathrm{~m}$, 24.VII.2018, leg. V.G., M.M., V.L.; $5 \sigma^{\top} \sigma^{7}, 1$ (ASU), same Republic, Kosh-Agach District, 2 air-km NE of Kurai, valley of Kuraika River, left bank, 1.52 air-km up the river from Chuya Tract, $50.24651^{\circ} \mathrm{N}, 87.95520^{\circ} \mathrm{E}$, riverine Larix sibirica forest, ca $1590 \mathrm{~m}$ a.s.1., under stones and in litter, 24.VII.2018, leg. P.N., V.G.; $1 \sigma^{7}, 1$ क, 1 juv. (ASU), same Republic and District, 20 air-km NE of Kokorya, Chikhachiova Mt. Range, Talduair massif, right bank of Sailyugem River, $50.01802^{\circ} \mathrm{N}, 89.23557^{\circ} \mathrm{E}$, floodplain Larix sibirica forest, $2225 \mathrm{~m}$ a.s.1., under stones, 26.VII.2018, leg. P.N., M.M., V.L.; 1 juv. (ASU), same Republic and District, 26 air-km NNW of Belyashi (=Dzhazator), valley of Karagem River, floodplain, $49.88593^{\circ} \mathrm{N}$, $87.19024^{\circ} \mathrm{E}$, riverine Populus forest with Larix sibirica, ca $1355 \mathrm{~m}$ a.s.1., in litter, 29.VII.2018; 1 juv. (ASU), near s.1., W macroslope of Yuzhno-Chuiskii Mt. Range, $49.88531^{\circ} \mathrm{N}, 87.19548^{\circ} \mathrm{E}$, moraines on left bank of Karagem River, Larix sibirica forest with Caragana arborescens, ca $1385 \mathrm{~m}$ a.s.l., in litter and in moss, 29. VII.2018; 1 juv. (ASU), near s.1., $49.88194^{\circ} \mathrm{N}, 87.20650^{\circ} \mathrm{E}$, Larix sibirica and Picea obovata forest with Caragana arborescens, Alnus and green mosses, ca $1560 \mathrm{~m}$ a.s.l., under stones and in moss, 29.VII.2018; 1 \% (ASU), near s.1., 49.88080 ${ }^{\circ} \mathrm{N}, 87.20740^{\circ} \mathrm{E}$, Larix sibirica forest on W slope in brook valley, ca $1590 \mathrm{~m}$ a.s.1., in moss, 29.VII.2018; $1 \sigma^{7}, 1$ juv. (ASU), same Republic and District, 8 air-km NNE of Kosh-Agach, Kurai Mt. Range, valley of Tabozhok River, foot of NW slope of Mt Tabozhok, $50.07596^{\circ} \mathrm{N}, 88.72931^{\circ} \mathrm{E}$, Larix sibirica forest with Alnus, ca $2065 \mathrm{~m}$ a.s.1., under stones, all leg. P.N.; $1 \overbrace{}^{7}, 3$ juv. (ASU), same Republic, Ust-Kan District, 2 air-km SW of Ust-Kan, valley of Kutergen River, $50.90546^{\circ} \mathrm{N}$, $84.73464^{\circ}$ E, Picea obovata forest with Spiraea and green mosses on left river bank, ca $1180 \mathrm{~m}$ a.s.l., in and under moss, covering big stones, 19.VIII.2018; 1 ऽ , 2 OO (ASU), same Republic and District, 2.5 air-km SW of Ust-Kan, $50.91489^{\circ} \mathrm{N}, 84.71967^{\circ} \mathrm{E}$, Betula pendula and Larix sibirica forest with Pinus sibirica, Alnus, Cotoneaster, Rosa spinosissima and tall grass vegetation on $\mathrm{S}$ slope, $1450 \mathrm{~m}$ a.s.1., in green moss, 19.VIII.2018, all leg. P.N.

DISTRIBUTION. A trans-Siberian species, L. (E.) sibiricus is widespread in the Asian part of Russia and northern Mongolia [Gerstfeldt, 1859; Sseliwanoff, 1880a, b, 1881a; Attems, 1909; Molodova, 1972; Alekseeva, 1974; Eason, 1976; Kurcheva, 1977; Zalesskaja, 1978; Vorobiova, 1999; Nefediev, 2001; Vorobiova et al., 2002; Nefediev, Aripov, 2013; Poloczek et al., 2016; Nefediev et al., 2016, 2017a, b, c, 2018, 2020; Dyachkov, 2017a, b].

REMARKS. The above abundant new records of this species clarify its distribution area in SW Siberia.

\section{Lithobius vagabundus Stuxberg, 1876 Map 5.}

Lithobius vagabundus Stuxberg, 1876a: 28, 29: fig, 1876b: 314. Lithobius vagabundus - Eason, 1976: 111, 112-113: figs; Zalesskaja, 1978: 166, 167: figs; Nefediev, Aripov, 2013: 41; Nefediev et al., 2017b: 13; 2018: 236.

Lithobius cf. vagabundus - Nefediev et al., 2017a: 219, 218: map.

non Lithobius vagabundus pro parte - Stuxberg, 1876a: 28, 29: fig, 1876b: 314

non Lithobius vagabundus - Muralewitsch, 1906: 69.

MATERIAL EXAMINED. 2 juv. (ASU), Russia, Republic of Altai, Ulagan District, 15 air-km NNW of Aktash, near Lake 


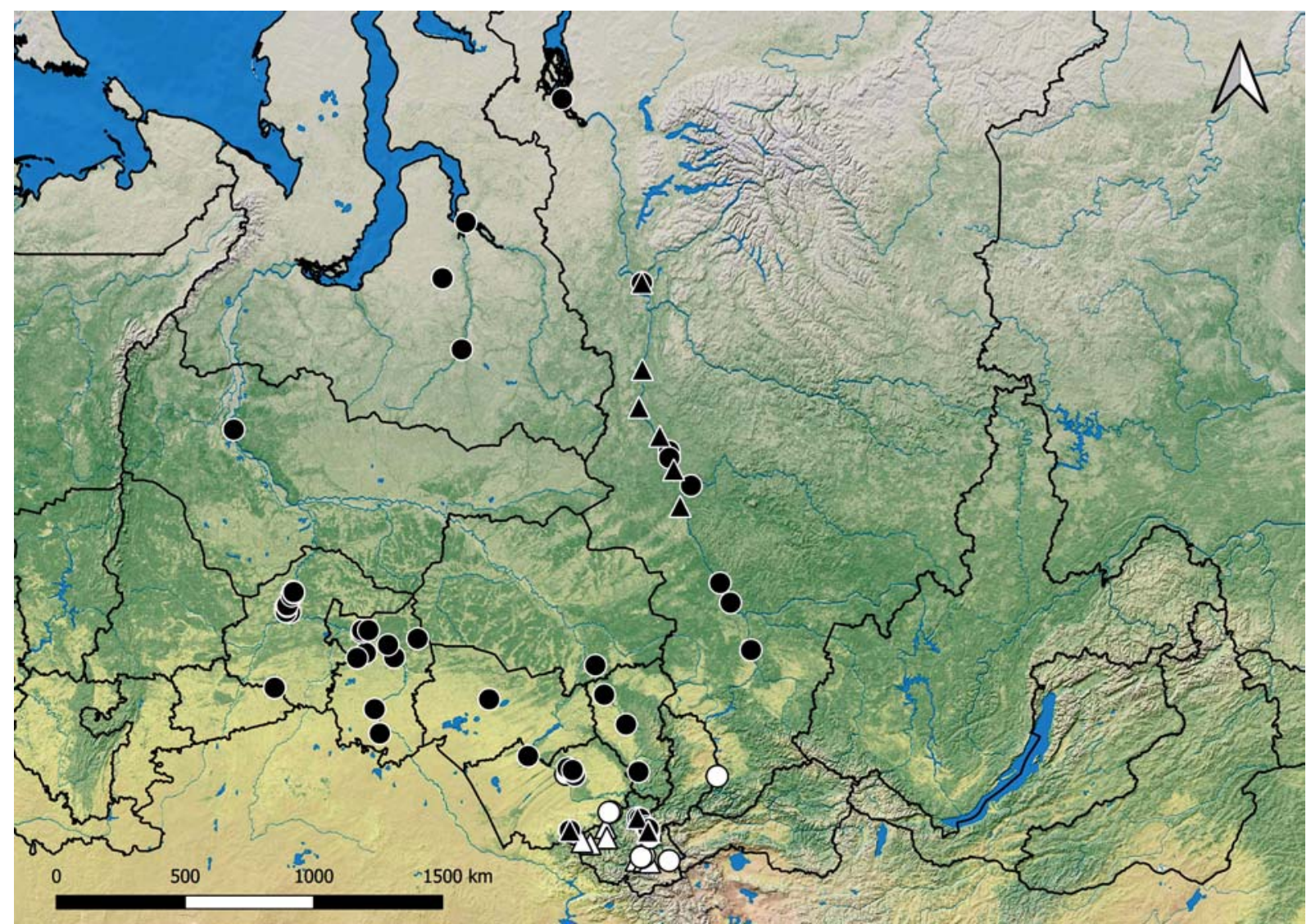

Fig. 5. Distributions of Lithobius vagabundus Stuxberg, 1876 (triangle) and L. (Monotarsobius) curtipes C.L. Koch, 1847 (circle) in Siberia. Previously known localities marked in black, new records given in white.

Рис. 5. Распространение Lithobius vagabundus Stuxberg, 1876 (треугольник) и L. (Monotarsobius) curtipes C.L. Koch, 1847 (круг) в Сибири. Черным отмечены ранее известные места находок, новые находки отмечены белым.

Taldukiol, $50.442204^{\circ} \mathrm{N}, 87.535498^{\circ} \mathrm{E}$, sparse Larix sibirica forest with Betula rotundifolia, $1840 \mathrm{~m}$ a.s.1., soil sample $(0-10 \mathrm{~cm}$ deep), 17-18.VII.2006; 1 क (PSU-1238), same Republic and District, 5.5 air-km SE of Aktash, Starye Miony, near Kara-Tyt Spring, floodplain of Mionka River, $50.281032^{\circ} \mathrm{N}, 87.680762^{\circ} \mathrm{E}$, Picea obovata forest with green mosses, $1410 \mathrm{~m}$ a.s.1., 20.VII.2006; 1 \% (PSU-1241), 3 우, 1 juv. (ASU), same Republic and District, ca 21 air-km N of Aktash, Ulagan Pass, $50.501562^{\circ} \mathrm{N}, 87.655555^{\circ} \mathrm{E}$, sparse Pinus sibirica forest with Betula rotundifolia, in moss, ca 2065 m a.s.1., 31.VII.2006; 1 \% (ASU), same Republic and District, ca 18 air-km NNW of Aktash, E part of Lake Sorulukiol, 50. $456706^{\circ} \mathrm{N}, 87.486864^{\circ} \mathrm{E}$, Betula rotundifolia with Carex on slope near lake shore, $1825 \mathrm{~m}$ a.s.1., 13.VIII.2007, all leg. P.N., J.N.; 1 O cf. vagabundus (ASU), same Republic, Shebalino District, ca 10 $\mathrm{km} \mathrm{S}$ of Cherga on Chuya Tract, Betula pendula and Larix sibirica forest, p.t., 21.VII.2006, leg. M.S.; $1 \sigma^{\top}$ (PSU-1016), same Republic and District, 3.5 air-km SE of Topuchaya, $51.11235^{\circ} \mathrm{N}, 85$ $63166^{\circ} \mathrm{E}$, mixed herbaceous meadow, ca $1435 \mathrm{~m}$ a.s.1., p.t., 20-22 VII.2018, leg. P.N.; 2 O$^{\top} \sigma^{\top}, 2$ 2 , 8 juv. (PSU-1020), 6 90,5 juv. (ASU), near s.1., $51.11189^{\circ} \mathrm{N}, 85.63219^{\circ} \mathrm{E}$, Betula pendula, Larix sibirica, Pinus sibirica and Picea obovata forest with Alnus, Lonicera, Ribes nigrum and tall grass vegetation on hummocks, along brook, ca $1435 \mathrm{~m}$ a.s.1., b.h., sifted leaf litter, p.t., 20-22.VII. 2018, leg. P.N., V.G., M.M., V.L.; $1 \sigma^{7}, 1$ (ASU), same Republic, Ongudai District, 20 air-km W of Chibit, valley of Chuya River, near Shirlak Waterfall, right bank of Chuya River, $50^{\circ} 20.615^{\prime} \mathrm{N}$, $87^{\circ} 13.335^{\prime} \mathrm{E}$, Betula forest with Larix sibirica, Caragana, shortgrass vegetation and green mosses, ca $1015 \mathrm{~m}$ a.s.1., 23.VII.2018; 1 (ASU), near s.1., environs of Shirlak Waterfall, along Tektu River down the waterfall, $50^{\circ} 20.725^{\prime} \mathrm{N}, 87^{\circ} 13.149^{\prime} \mathrm{E}$, Betula pendula forest with Alnus, ca 1080 m a.s.1., 23.VII.2018, all leg. P.N.; 1 q (ASU), near s.1., $50^{\circ} 20.690^{\prime} \mathrm{N}, 87^{\circ} 13.213^{\prime} \mathrm{E}$, Betula grove along creek, ca $1080 \mathrm{~m}$ a.s.1., sifting leaf litter over $40 \mathrm{~m}, 23$.VII.2018; 4 $\sigma^{\top} \sigma^{7}, 1$ juv. (PSU-1005), same Republic, Ulagan District, 4 air-km $\mathrm{NE}$ of Aktash, valley of Yarlyamry River, $50^{\circ} 19.912^{\prime} \mathrm{N}, 8^{\circ} 39.539^{\prime} \mathrm{E}$, forest with Picea obovata, Pinus sibirica, Larix sibirica, Vaccinium vitis-idaea, Equisetum, Lonicera, ca $1640 \mathrm{~m}$ a.s.1., sifting leaf litter and moss over 50 m, 24.VII.2018, all leg. V.G., M.M., V.L.; 4 juv. cf. vagabundus (ASU), near s.1., $50.33167^{\circ} \mathrm{N}, 87.65897^{\circ} \mathrm{E}$, Picea obovata taiga forest with Larix sibirica, Vaccinium vitisidaea and Alnus, ca $1615 \mathrm{~m}$ a.s.1., in green mosses, 24.VII.2018; 1 juv. (ASU), same Republic, Kosh-Agach District, $5.5 \mathrm{~km} \mathrm{NNE} \mathrm{of}$ Kurai, S macroslope of Kurai Mt. Range, valley of Kuraika River, left river bank, $50.28225^{\circ} \mathrm{N}, 87.95463^{\circ} \mathrm{E}$, Larix sibirica and Picea obovata forest with Pinus sibirica, Caragana, small grass vegetation and green mosses, ca $1790 \mathrm{~m}$ a.s.1., in moss, under logs, 25.VII.2018; 1 juv. (ASU), same Republic, Ust-Kan District, 1.7 air-km SW of Ust-Kan, $50.91142^{\circ} \mathrm{N}, 84.73499^{\circ} \mathrm{E}$, Betula pendula and Picea obovata forest with green moss o N slope, ca $1180 \mathrm{~m}$ a.s.1., in green moss and rotten trunk, 19.VIII.2018, all leg. P.N.; 1 q, 1 juv. (PSU-1006), Russia, Altai Province, Charyshskoye District, 5 air-km S of Ust-Kumir, valley of Kumir River, $50^{\circ} 59.140^{\prime} \mathrm{N}$, $84^{\circ} 17.392^{\prime} \mathrm{E}$, meadow with tall herbaceous vegetation, ca $790 \mathrm{~m}$ a.s.1., p.t., 31.VII.-01.VIII.2018, leg. V.G., M.M., V.L.

DISTRIBUTION. This species was originally described by Stuxberg from the Yenisei River region, Krasnoyarsk Province, central Siberia [Stuxberg, 1876a, b]. A century later, Lithobius vagabundus was redescribed from type material, with lectotype designation [Eason, 1976]. The record 
of this species from the Kanin Peninsula, Nenets Autonomous Region [Muralewitsch, 1906] is a misidentification (see Eason [1976]). It has recently been found in the Altai Province [Nefediev et al., 2017b, 2018] and provisionally in the Republic of Altai [Nefediev et al., 2017a], both SW Siberia.

REMARKS. The abundant new records of L. vagabundus cover the central, SE and SW parts of the Republic of Altai.

\section{Lithobius (Monotarsobius) curtipes C.L. Koch, 1847} Map 5.

Lithobius captivus Stuxberg, 1876a: 29; 1876b: 314.

Lithobius captivus - Eason, 1976: 115, fig.

Monotarsobius curtipes - Zalesskaja, 1978: 178, 180: figs; Vorobiova, 1999: 33; Rybalov, 2002: 82; Vorobiova et al., 2002: 61; Striganova, Poryadina, 2005: 226.

Lithobius curtipes — Sergeeva, 2010: 37; Bukhkalo, Sergeeva, 2012: 61; Sergeeva, 2013: 530; Bukhkalo et al., 2014: 71.

Lithobius (Monotarsobius) curtipes - Sergeeva, 2010: 38; Nefediev et al., 2016: 263, 260: map; 2017a: 219, 218: map 2017b: 13; 2017c: 116, 117: map; 2018: 232; Nefediev et al., 2020: 41, 40: map.

MATERIAL EXAMINED. 1 (ASU), Russia, Republic of Altai, Ulagan District, 15 air-km NNW of Aktash, Lake Taldukiol, $50.443294^{\circ} \mathrm{N}, 87.534489^{\circ} \mathrm{E}$, sparse Larix sibirica forest with Betula rotundifolia, ca $1840 \mathrm{~m}$ a.s.1., in litter and moss, 18.VII.2006 2 우, 2 juv. (ASU), same Republic and District, Kalbakaya River, Betula rotundifolia, in moss, 25.VII.2006; $5 \checkmark^{7} \sigma^{7}, 1$ ㅇ (PSU-1246), same Republic and District, ca 21 air-km N of Aktash, Ulagan Pass, $50.501562^{\circ} \mathrm{N}, 87.655555^{\circ} \mathrm{E}$, sparse Pinus sibirica forest with Betula rotundifolia in moss, ca $2065 \mathrm{~m}$ a.s.1., 31.VII.2006; 10 (ASU), same Republic and District, ca 18 air-km NNW of Aktash, E part of Lake Sorulukiol, $50.456706^{\circ} \mathrm{N}, 87.486864^{\circ} \mathrm{E}$, Betula rotundifolia with Carex on slope near lake shore, $1825 \mathrm{~m}$ a.s.l. 13.VIII.2007; $3 \bigcirc^{7} \sigma^{7}, 2$ 우, 1 juv. (ASU), same Republic and District, Altai State Nature Reserve, Stone Mushrooms (= Akkurum), $51^{\circ} 06^{\prime} 40^{\prime \prime} \mathrm{N}, 87^{\circ} 58^{\prime} 33^{\prime \prime} \mathrm{E}$, Betula pendula patch between two groups of rocks, $730 \mathrm{~m}$ a.s.1., 5.VII.2016, all leg. P.N., J.N.; 1 O (ASU), same Republic, Maima District, Maima, bank of Maima River sleeve, $51.988804^{\circ} \mathrm{N}, 85.872340^{\circ} \mathrm{E}$, Salix and Acer negundo with ruderal vegetation, ca $260 \mathrm{~m}$ a.s.1., under stones, 20.VII.2018, leg. P.N.; 1 (ASU), Russia, Altai Province, Barnaul, Yuzhnyi, mixed forest, 27.VI.2010; 1 q (ASU), same Province, Altaiskoye District, ca 5 air-km NW of Aya, Lake Aichionok, Betula pendula patch on slope of Mt Tipeshka, in litter, 7.VII.2010, all leg. P.N.; $\sigma^{\top} 3$ 우 (ASU), same Province, Kalmanka District, between Stukovo and Shtabka, Pinus sylvestris forest with Betula pendula, 28.VIII.2017, leg. P.N., A.N.; $2 \sigma^{7} \sigma^{\top}, 2$ 우 (PSU-824), Russia, Republic of Khakassia, Altai District, Ochurskii Bor, $53^{\circ} 09^{\prime} 33$. $5^{\prime \prime} \mathrm{N}, 91^{\circ} 36^{\prime} 35.9^{\prime \prime} \mathrm{E}$, Pinus sylvestris forest, 30.IX.2008, leg. D.P.

DISTRIBUTION. A trans-Palaearctic species, L. (M.) curtipes shows an extremely wide distribution area in Europe, the Urals, the Near East, the Arabian Peninsula, the Asian part of Russia, Kazakhstan, and also in northern Mongolia [Dobroruka, 1960; Zalesskaja, 1978; Farzalieva, Esyunin, 2008; Bonato et al., 2016; Poloczek et al., 2016; Dyachkov, 2019]. In Siberia, this species has previously been recorded from the Altai and Krasnoyarsk provinces, the Novosibirsk, Omsk, Tyumen and Tomsk areas, the KhantyMansi Autonomous and Yamalo-Nenets Autonomous regions, and the Republic of Altai [Zalesskaja, 1978; Vorobiova, 1999; Rybalov, 2002; Vorobiova et al., 2002; Striganova, Poryadina, 2005; Sergeeva, 2010, 2013; Bukhkalo, Sergeeva, 2012; Nefediev et al., 2016, 2017a, b, c, 2018], recently also from the Kemerovo Area [Nefediev et al., 2020].
REMARKS. This species is formally recorded from the Republic of Khakassia for the first time.

\section{Lithobius (Monotarsobius) franciscorum Dányi et Tuf, 2012 Map 6.}

Lithobius (Monotarsobius) franciscorum - Nefediev et al., 2017a: 220, map; Dyachkov, 2017b: 454.

MATERIAL EXAMINED. 1 (ASU), Russia, Republic of Altai, Ongudai District, ca 3.5 air-km SW of Belyi Bom, valley of Syrnakh River, $50.347834^{\circ} \mathrm{N}, 86.998210^{\circ} \mathrm{E}$, along the road to Shavla Nature Reserve, Ribes nigrum, 1165 m a.s.1., 21.VII.2006; 1 우 (ASU), same Republic, Kosh-Agach District, ca 15 air-km S of Belyi Bom, patch of Larix sibirica forest, $50.233899^{\circ} \mathrm{N}, 87$. $004114^{\circ} \mathrm{E}, 1810 \mathrm{~m}$ a.s.1., 22.VII.2006; $10^{7}, 1$ q, 4 juv. (PSU1190), same Republic, Ulagan District, ca 21 air-km N of Aktash, Ulagan Pass, $50.501562^{\circ} \mathrm{N}, 87.655555^{\circ} \mathrm{E}$, sparse Pinus sibirica forest with Betula rotundifolia, in moss, ca $2065 \mathrm{~m}$ a.s.1., 31.VII. 2006; 1 + (ASU), same Republic and District, ca $9 \mathrm{~km} \mathrm{~N}$ of Aktash, $50.382399^{\circ} \mathrm{N}, 87.620410^{\circ} \mathrm{E}$, Pinus sibirica forest on slope, $1840 \mathrm{~m}$ a.s.1., 31.VII.2006; 3 우 (PSU-1278), same Republic, Ongudai District, Seminskii Pass, $51.047968^{\circ} \mathrm{N}, 85.607156^{\circ} \mathrm{E}$, sparse Pinus sibirica forest, $1700 \mathrm{~m}$ a.s.1., 6.VII.2016, all leg. P.N., J.N.; 3 O $^{7}, 2$ ㅇ, 1 juv. (ASU), same Republic, Shebalino District, 3.5 air-km SE of Topuchaya, $51.11235^{\circ} \mathrm{N}, 85.63166^{\circ} \mathrm{E}$, mixed herbaceous meadow, ca $1435 \mathrm{~m}$ a.s.1., p.t., 20-22.VII.2018, leg. P.N.; $2 \sigma^{7} \sigma^{7}, 2$ 90,8 juv. (PSU-1020), 6 +o, 5 juv. (ASU), near s.1., $51.11189^{\circ} \mathrm{N}, 85.63219^{\circ} \mathrm{E}$, Betula pendula, Larix sibirica, Pinus sibirica and Picea obovata forest with Alnus, Lonicera, Ribes nigrum and tall grass vegetation on hummocks, along brook, ca $1435 \mathrm{~m}$ a.s.1., b.h., sifted leaf litter, p.t., 20-22.VII.2018, leg. P.N., V.G., M.M., V.L.; 1 フ 1 ( (PSU-1031), same Republic, Shebalino District, 10 air-km NE of Seminskii Pass, Seminskii Mt. Range, summit of Mt Sarlyk, $51^{\circ} 04.633^{\prime} \mathrm{N}, 85^{\circ} 44.134^{\prime} \mathrm{E}$, rocky desert with patches of mountain tundra, under stones, $2505 \mathrm{~m}$ a.s.1., 21.VII.2018, leg. P.N.; $1 \sigma^{7}$ (ASU), same Republic, Ongudai District, ca 7.5 airkm NEE of Seminskii Pass, Seminskii Mt. Range, near Mt Sarlyk, $51^{\circ} 03.737^{\prime} \mathrm{N}, 85^{\circ} 42.492^{\prime} \mathrm{E}$, alpine meadow belt, patches of Betula rotundifolia, Salix, dwarf Juniperus, sparse Picea obovata and Larix sibirica woodland, ca $1955 \mathrm{~m}$ a.s.l., sifting leaf litter and moss over 80 m, 21.VII.2018, leg. V.G., M.M., V.L.; $1 \sigma^{7}$ (PSU1030), same Republic and District, 10.5 air-km NE of Seminskii Pass, Seminskii Mt. Range, foot of Mt Sarlyk, Lakes Tuyukskiye, $51^{\circ} 04.547^{\prime} \mathrm{N}, 85^{\circ} 44.560^{\prime} \mathrm{E}$, mountain tundra, under stones, ca 2230 $\mathrm{m}$ a.s.1., 21.VII.2018; 1 (ASU), same Republic and District, 20 air-km W of Chibit, valley of Chuya River, near Shirlak Waterfall, right bank of Chuya River, $50^{\circ} 20.615^{\prime} \mathrm{N}, 87^{\circ} 13.335^{\prime} \mathrm{E}$, Betula forest with Larix sibirica, Caragana, small grass vegetation and green mosses, ca $1015 \mathrm{~m}$ a.s.1., 23.VII.2018; $1 \sigma^{7}, 1$ \% (ASU), near s.l., environs of Shirlak Waterfall, along Tektu River down the waterfall, $50^{\circ} 20.725^{\prime} \mathrm{N}, 87^{\circ} 13.149^{\prime} \mathrm{E}$, Betula pendula forest with Alnus, ca $1080 \mathrm{~m}$ a.s.1., 23.VII.2018; 1 juv. (PSU-1008), same Republic, Ulagan District, 3 air-km NW of Chibit, foot of SW slope, scattered Picea obovata and Berberis, $50^{\circ} 20.008^{\prime} \mathrm{N}, 87^{\circ}$ $27.688^{\prime}$ E, ca $1125 \mathrm{~m}$ a.s.1., 23.VII.2018, all leg. P.N.; $2 \sigma^{\top} \sigma^{\top}, 2$ 우, 1 juv. (PSU-1001), same Republic and District, 10 air-km ENE of Aktash, Kurai Mt. Range, summit with retranslator, $50.33958^{\circ} \mathrm{N}$, $87.74865^{\circ} \mathrm{E}$, rocky mountain tundra, ca $2970 \mathrm{~m}$ a.s.1., under stones, 23.VII.2018, leg. P.N., V.G., M.M., V.L.; 1 ㅇ (ASU), same Republic and District, 3.5 air-km NE of Aktash, valley of Yarlyamry River, $50^{\circ} 20.027^{\prime} \mathrm{N}, 87^{\circ} 38.945^{\prime} \mathrm{E}$, forest with Picea obovata, Larix sibirica, Pinus sibirica, Caragana arborescens, Lonicera, Ribes nigrum, moss, $1575 \mathrm{~m}$ a.s.l., sifting leaf litter and moss over $50 \mathrm{~m}$, 24.VII.2018; 1 juv. (ASU), same Republic and District, 4 air-km $\mathrm{NE}$ of Aktash, valley of Yarlyamry River, $50^{\circ} 19.912^{\prime} \mathrm{N}, 87^{\circ} 39$. 539'E, forest with Picea obovata, Pinus sibirica, Larix sibirica, Vaccinium vitis-idaea, Equisetum, Lonicera, ca 1640 m a.s.1., sifting leaf litter and moss over $50 \mathrm{~m}, 24$.VII.2018, all leg. V.G., M.M., V.L.; 1 (PSU-1026), same Republic, Kosh-Agach District, 14 air-km W of Belyashi (=Dzhazator), valley of Koksu River, left bank, Picea obovata forest with Caragana arborescens, Vaccini- 


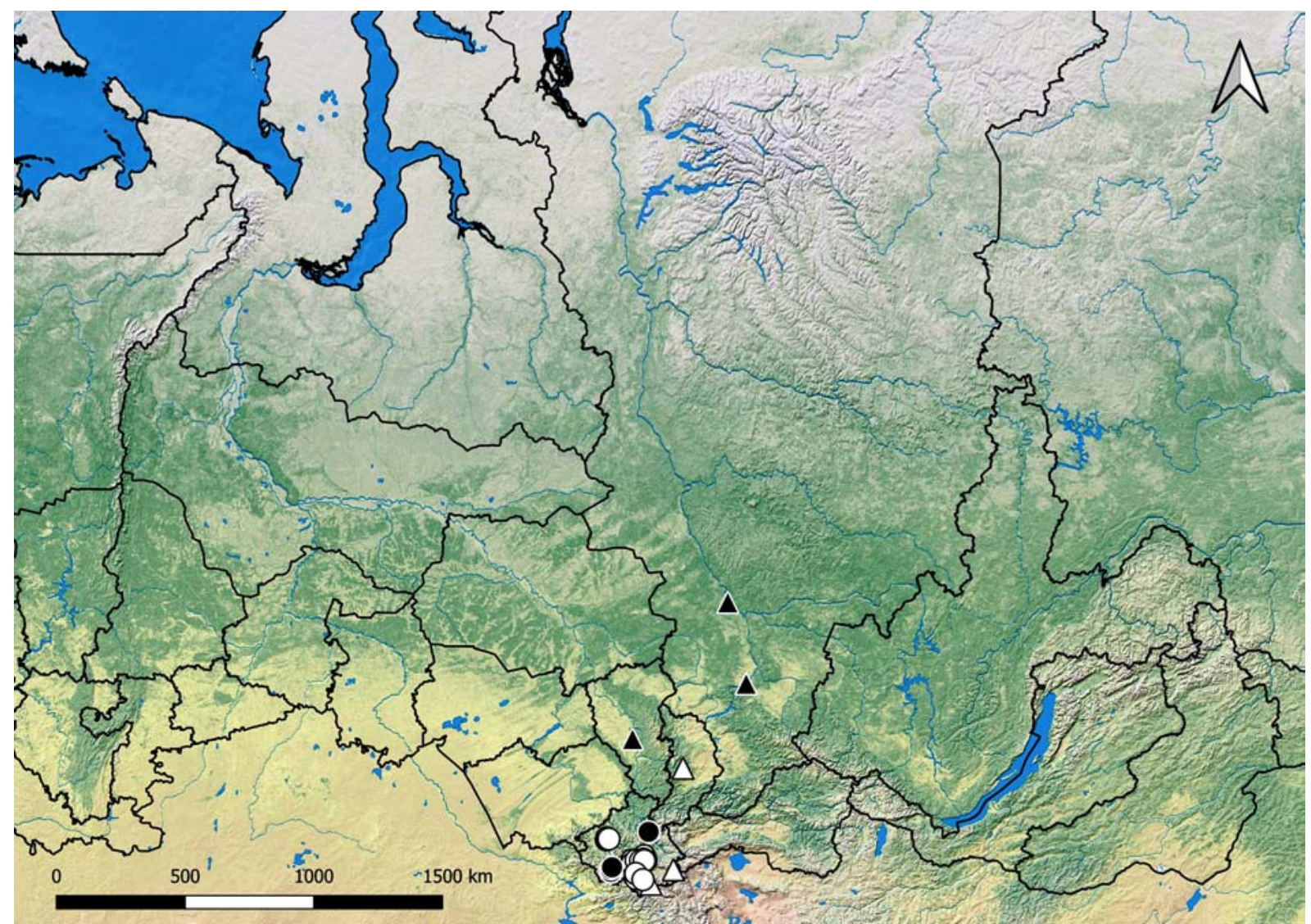

Fig. 6. Distributions of Lithobius (Monotarsobius) franciscorum Dányi et Tuf, 2012 (circle) and L. (M.) fugax Stuxberg, 1876 (triangle) in Siberia. Previously known localities marked in black, new records given in white.

Рис. 6. Распространение Lithobius (Monotarsobius) franciscorum Dányi et Tuf, 2012 (круг) и L. (M.) fugax Stuxberg, 1876 (треугольник) в Сибири. Черным отмечены ранее известные места находок, новые находки отмечены белым.

um vitis-idaea and green moss, $49.70599^{\circ} \mathrm{N}, 87.21581^{\circ} \mathrm{E}$, ca 1605 $\mathrm{m}$ a.s.1., 28.VII.2018; 1 9 (ASU), same Republic and District, 26 air-km NNW of Belyashi (=Dzhazator), valley of Karagem River, W macroslope of Yuzhno-Chuiskii Mt. Range, open W slope with Spiraea thicket, $49.88120^{\circ} \mathrm{N}, 87.20644^{\circ} \mathrm{E}$, ca $1575 \mathrm{~m}$ a.s.l., under stones and in moss, 29.VII.2018; 1 क (ASU), near s.1., $49.88201^{\circ} \mathrm{N}$, $87.20499^{\circ} \mathrm{E}$, Larix sibirica forest with Alnus and young Betula pendula, $1545 \mathrm{~m}$ a.s.1., in green mosses, 29.VII.2018, all leg. P.N.; 1 ㅇ, 1 juv. (PSU-1010), near s.1., 49 $53.237^{\prime} \mathrm{N}, 87^{\circ} 11.520^{\prime} \mathrm{E}$, wet ravine along river, forest with Picea obovata, Larix sibirica and Populus, moss, ca $1355 \mathrm{~m}$ a.s.l., sifting leaf litter and moss over 100 m, 29.VII.2018, leg. V.G., M.M., V.L.; $10^{7}$ (PSU-1015), same Republic and District, 12 air-km ESE of Belyashi (=Dzhazator), $49.67046^{\circ} \mathrm{N}, 87.59002^{\circ} \mathrm{E}$, Picea obovata forest with green mosses and small grass vegetation, ca $1615 \mathrm{~m}$ a.s.l., in litter and in moss, 30.VII.2018, leg. P.N.

DISTRIBUTION. Originally described by Dányi \& Tuf [2012] from Eastern Kazakhstan, L. (M.) franciscorum has recently been recorded from the Altai State Nature Biosphere Reserve in the NE part of the Republic of Altai (environs of Lake Teletskoye) [Nefediev et al., 2017a], and also from the Katun State Nature Reserve [Dyachkov, 2017b].

REMARKS. The above records expand the distribution area of this species to central and southeastern regions of the Republic of Altai.

Lithobius (Monotarsobius) fugax Stuxberg, 1876 Map 6.
Lithobius fugax Stuxberg, 1876a: 27, 28: fig.; 1876b: 313.

Monotarsobius fugax — Attems, 1909: 18; Zalesskaja, 1978: 183, figs.

Lithobius fugax — Eason, 1976: 108, 109: figs; Nefediev, Aripov, 2013: 41

Lithobius (Monotarsobius) fugax - Nefediev et al., 2020: 41, 39: map.

non Lithobius fugax - Sseliwanoff, 1881a: 9, inset: fig.

MATERIAL EXAMINED. 1 \& (PSU), Russia, Republic of Altai, Ulagan District, ca 18 air-km NNW of Aktash, NE part of Lake Sorulukiol, $50.463823^{\circ} \mathrm{N}, 87.485185^{\circ} \mathrm{E}$, Pinus sibirica forest with Larix sibirica, Vaccinium vitis-idaea, green mosses, $1890 \mathrm{~m}$ a.s.1., 13.VIII.2007, all leg. P.N., J.N.; 1 of. fugax (PSU-1021), same Republic, Kosh-Agach District, 20 air-km NE of Kokorya, Chikhachiova Mt. Range, Talduair massif, right bank of Sailyugem River, bottom of S slope, $50.01770^{\circ} \mathrm{N}, 89.23775^{\circ} \mathrm{E}$, scree with Astragalus, Artemisia, Comarum salesovianum, ca 2245 m a.s.1., under stones lying on bush branches, in herb debris, 26.VII.2018; 1 of. fugax (ASU), same Republic and District, 47 air-km ESE of Belyashi (=Dzhazator), valley of Zhumaly River, $49.51252^{\circ} \mathrm{N}$, $88.01705^{\circ} \mathrm{E}$, rocky plateau with Dryas patches on E slope, $2415 \mathrm{~m}$ a.s.1., under stones, 27.VII.2018, all leg. P.N.;1 9 (PSU-815), Russia, Republic of Khakassia, Askiz District, valley of Askiz River, $53.419057^{\circ} \mathrm{N}, 89.756044^{\circ} \mathrm{E}$, ca $680 \mathrm{~m}$ a.s.1., under stones, 4.VIII. 2018, leg. S.D.

DISTRIBUTION. This species was originally described by Stuxberg $[1876 \mathrm{a}$, b] from the Yenisei River region, Krasnoyarsk Province, central Siberia, later redescribed with lectotype designation, and synonymized with Monotarsobius kaszabi Loksa, 1965, the latter species recorded from 


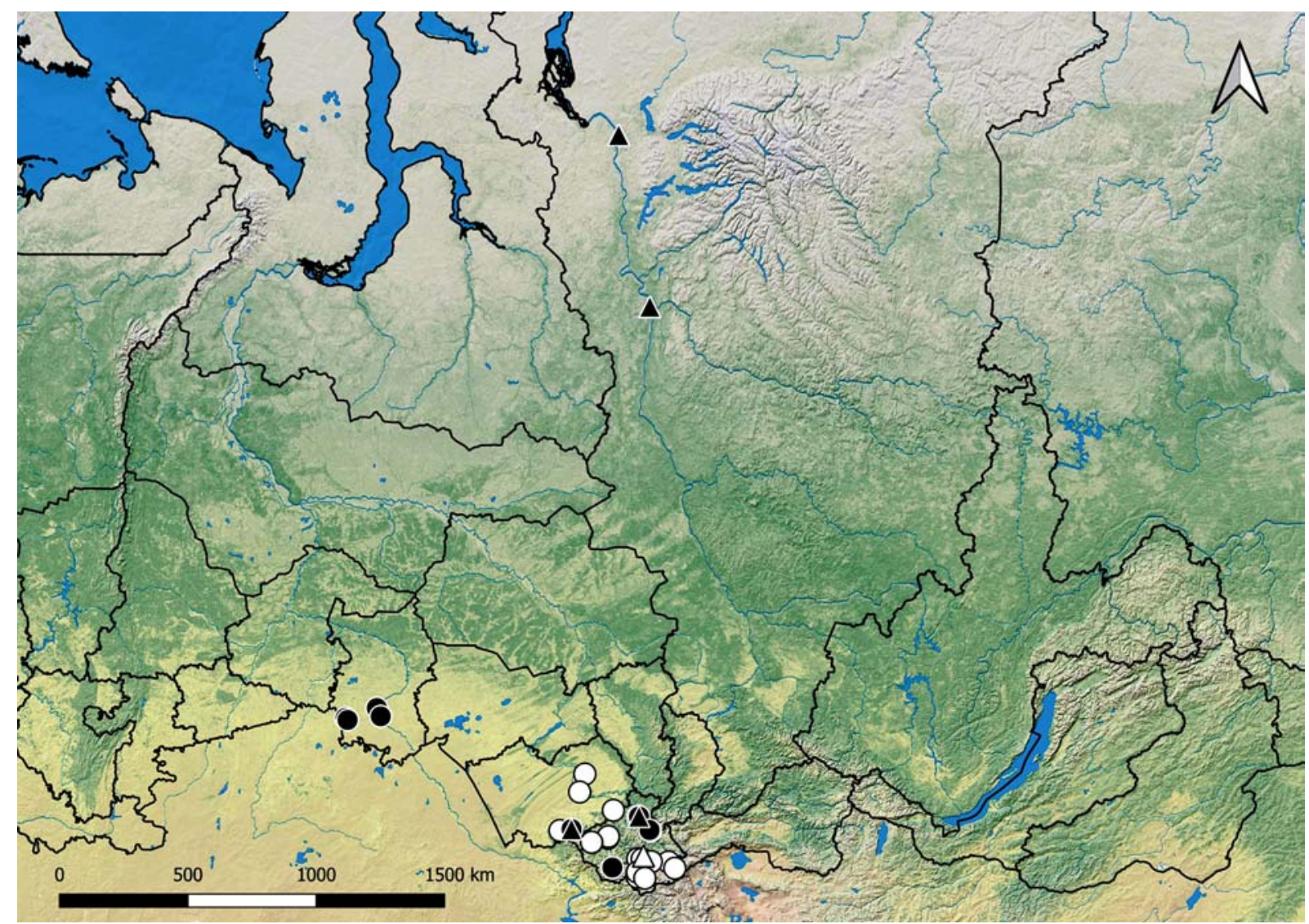

Fig. 7. Distributions of Lithobius (Monotarsobius) insolens Dányi et Tuf, 2012 (circle) and L. (M.) nordenskioeldii Stuxberg, 1876 (triangle) in Siberia. Previously known localities marked in black, new records given in white.

Рис. 7. Распространение Lithobius (Monotarsobius) insolens Dányi et Tuf, 2012 (круг) и L. (M.) nordenskioeldii Stuxberg, 1876 (треугольник) в Сибири. Черным отмечены ранее известные места находок, новые находки отмечены белым.

Mongolia [Eason, 1976]. This species has recently been found in the Kemerovo Area, SW Siberia [Nefediev et al., 2020].

REMARKS. Lithobius (M.) fugax has hitherto been recorded neither in the Republic of Altai nor in the Republic of Khakassia, both southwestern Siberia.

\section{Lithobius (Monotarsobius) insolens Dányi et Tuf, 2012 Map 7.}

Lithobius (Monotarsobius) insolens - Nefediev et al., 2017a: 221, 220: map; 2017b: 13; 2017c: 116, 117: map; 2018: 233; Dyachkov, 2017b: 454.

MATERIAL EXAMINED. 1 juv. (ASU), Russia, Republic of Altai, Ulagan District, valley of Bashkaus River, Betula rotundifolia, b.h., 25.VII.2006; 2 丁 $^{7}, 2$ 2 + (ASU), same Republic, Maima District, Gorno-Altaisk, floodplain of Maima River, foot of Mt Tugaya, $51.995684^{\circ} \mathrm{N}, 85.902017^{\circ} \mathrm{E}$, Betula pendula and Acer negundo, ca $275 \mathrm{~m}$ a.s.1., 9.X.2014; $2 \sigma^{7} \sigma^{7}, 1$ q (PSU-1277), same Republic, Ongudai District, Seminskii Pass, $51.047968^{\circ} \mathrm{N}, 85$. $607156^{\circ} \mathrm{E}$, sparse Pinus sibirica forest, $1700 \mathrm{~m}$ a.s.1., 6.VII.2016, all leg. P.N., J.N.; 1 (ASU), same Republic, Shebalino District, 3.5 air-km SE of Topuchaya, $51.11235^{\circ} \mathrm{N}, 85.63166^{\circ} \mathrm{E}$, mixed herbaceous meadow, ca $1435 \mathrm{~m}$ a.s.1., b.h., 20.VII.2018, leg. P.N.; $1 \sigma^{7}, 1$ (ASU), near s.1., 51.11189 ${ }^{\circ} \mathrm{N}, 85.63219^{\circ} \mathrm{E}$, Betula pendula, Larix sibirica, Pinus sibirica and Picea obovata forest with Alnus, Lonicera, Ribes nigrum and tall grass vegetation on hum- mocks, along brook, ca $1435 \mathrm{~m}$ a.s.l., b.h., sifted leaf litter, p.t., 20-22.VII.2018, leg. P.N., V.G., M.M., V.L.; $1 \overbrace{}^{7}$ (ASU), same Republic, Ongudai District, 20 air-km W of Chibit, valley of Chuya River, environs of Shirlak Waterfall, $50^{\circ} 20.670^{\prime} \mathrm{N}, 87^{\circ} 13.388^{\prime} \mathrm{E}$, riverine terrasse and slopes with Picea obovata, Betula, Caragana arborescens, $1000 \mathrm{~m}$ a.s.l., sifting flood refuse and leaf litter at river banks and on slopes over $300 \mathrm{~m}, 23$. VII.2018, leg. V.G., M.M., V.L.; $2 \bigcirc^{\top} \sigma^{\top}, 2$ 우, 1 juv. (PSU-1009), same Republic, Ulagan District, 3 air-km NW of Chibit, foot of SW slope, $50^{\circ} 20$. $008^{\prime} \mathrm{N}, 87^{\circ} 27.688^{\prime} \mathrm{E}$, scattered Picea obovata and Berberis, ca 1125 m, 23.VII.2018, leg. P.N.; $3 \sigma^{7} \sigma^{7}, 3$ of, 3 juv. (ASU), same Republic, Kosh-Agach District, 2 air-km NE of Kurai, valley of Kuraika River, left bank, 1.5-2 air-km up the river from Chuya Tract, $50.24651^{\circ} \mathrm{N}, 87.95520^{\circ} \mathrm{E}$, riverine Larix sibirica forest, ca $1590 \mathrm{~m}$ a.s.1., under stones and in litter, 24.VII.2018, leg. P.N. V.G.; $2 \bigcirc^{\top} \sigma^{\top}$ (ASU), same Republic and District, 20 air-km NE of Kokorya, Chikhachiova Mt. Range, Talduair massif, right bank of Sailyugem River, $50.01802^{\circ} \mathrm{N}, 89.23557^{\circ} \mathrm{E}$, floodplain Larix sibirica forest, $2225 \mathrm{~m}$ a.s.1., under stones, 26.VII.2018, leg. P.N., M.M., V.L.; $2 \sigma^{7} \sigma^{7}, 3$ 우, 1 juv. (ASU), same Republic and District, 14 air-km W of Belyashi (=Dzhazator), valley of Koksu River, left bank, $49.70599^{\circ} \mathrm{N}, 87.21581^{\circ} \mathrm{E}$, Picea obovata forest with Caragana arborescens, Vaccinium vitis-idaea and green moss, ca $1605 \mathrm{~m}$ a.s.1., 28.VII.2018, leg. P.N.; $2 \mathrm{O}^{\top} \sigma^{7}, 1$ juv. (ASU), near s.1., $49^{\circ} 42.369^{\prime} \mathrm{N}, 87^{\circ} 12.943^{\prime} \mathrm{E}$, forest with Picea obovata and Larix sibirica, ca $1610 \mathrm{~m}$ a.s.1., sifting leaf litter and moss over 200 m, 28.VII.2018, leg. V.G., M.M., V.L.; $1 \sigma^{7}$ (ASU), same Republic and District, 26 air-km NNW of Belyashi (=Dzhazator), valley of Karagem River, W macroslope of Yuzhno-Chuiskii Mt. Range, $49.88194^{\circ} \mathrm{N}, 87.20650^{\circ} \mathrm{E}$, Larix sibirica and Picea obovata forest 
with Caragana arborescens, Alnus and green mosses, ca $1560 \mathrm{~m}$ a.s.1., under stones and in moss, 29.VII.2018; 1 juv. (ASU), same Republic and District, 13.5 air-km ESE of Belyashi (=Dzhazator), valley of Uzurgu (=Tenektybulak/Terektybulak) River, $49.66981^{\circ} \mathrm{N}$, $87.60945^{\circ} \mathrm{E}$, Larix sibirica and Picea obovata forest with Pinus sibirica, ca $1635 \mathrm{~m}$ a.s.1., under stones, 30.VII.2018; $7 \sigma^{7} \sigma^{\top}, 1$ ㅇ, 4 juv. (ASU), same Republic, Ust-Kan District, 2 air-km SW of UstKan, valley of Kutergen River, $50.90546^{\circ} \mathrm{N}, 84.73464^{\circ} \mathrm{E}$, Picea obovata forest with Spiraea and green mosses on left river bank, ca $1180 \mathrm{~m}$ a.s.1., in and under moss, covering big stones, 19.VIII.2018; $1 \sigma^{7}, 1$ \%, 2 juv. (ASU), same Republic and District, 2.5 air-km SW of Ust-Kan, $50.91489^{\circ} \mathrm{N}, 84.71967^{\circ} \mathrm{E}$, Betula pendula and Larix sibirica forest with Pinus sibirica, Alnus, Cotoneaster, Rosa spinosissima and tall grass vegetation on S slope, $1450 \mathrm{~m}$ a.s.1., in green moss, 19.VIII.2018, all leg. P.N.; 5 + , 1 juv. (ASU), Russia, Altai Province, Kosikha District, near Ozero-Krasilovo, ASU Field Station, Lake Krasilovo, Pinus sylvestris, Betula pendula and Populus tremula forest with tall grass vegetation, p.t., 30.VI.-5.VII.2014; $6 \bigcirc^{7} \sigma^{7}, 5$ 9ᄋ, 3 juv. (PSU-1272), s.1., p.t., 5-10.VII.2014, all leg. P.N.; $2 \sigma^{\top} \sigma^{\top}, 4$ 우, 1 juv. (ASU), same Province, Krasnoshchiokovo District, near Chineta, Chineta Nature Reserve, $51^{\circ} 19^{\prime} \mathrm{N}, 83^{\circ}$ $00^{\prime} \mathrm{E}$, Betula pendula, Pinus sylvestris, Populus tremula with Caragana arborescens and Lonicera tatarica, on slope of hill, $480 \mathrm{~m}$ a.s.1., litter, 6.VI.2015, leg. P.N., J.N.; $2 \sigma^{\top} \sigma^{\top}, 2$ 90 , 1 juv. (PSU1266), same Province, Troitskoye District, near Chervyanka, young Pinus sylvestris forest, p.t., 15-24.VIII.2016; 2 + (ASU), near s.1., Pinus sylvestris forest, p.t., 16-25.VIII.2016, all leg. N.V.

DISTRIBUTION. A central Asian species, L. (M.) insolens was originally described by Farzalieva [2006: as L. (M.) insolitus] from Eastern Kazakhstan, later renamed to avoid homonymy (see Dányi \& Tuf [2012]). This species has recently been recorded from the Omsk Area [Nefediev et al., 2017c], the Altai Province [Nefediev et al., 2017b, 2018], and the Republic of Altai [Nefediev et al., 2017a; Dyachkov, 2017b].

REMARKS. The above records of $L$. (M.) insolens extend its distribution for the whole territory of the Republic of Altai and the central regions of the Altai Province.

\section{Lithobius (Monotarsobius) nordenskioeldii Stuxberg, 1876 Map 7.}

Lithobius Nordenskiöldii - Stuxberg, 1876a: 22, 23-24: figs; 1876b: 311; Nefediev, Aripov, 2013: 40.

Lithobius nordenskioldii - Eason, 1976: 105, 106: figs.

Lithobius (Monotarsobius) cf. nordenskioeldii - Nefediev et al., 2017a: 221, 220: map.

Lithobius (Monotarsobius) nordenskioldii - Nefediev et al., 2017b: 13 .

Lithobius (Monotarsobius) nordenskioeldii - Nefediev et al. 2018: 235 .

non Lithobius Nordenskiöldii pro parte - Stuxberg, 1876a: 22, 23-24: figs; 1876b: 311

MATERIAL EXAMINED. 1 (PSU-1244), Russia, Republic of Altai, Ulagan District, 15 air-km NNW of Aktash, near Lake Taldukiol, $50.442204^{\circ} \mathrm{N}, 87.535498^{\circ} \mathrm{E}$, sparse Larix sibirica forest with Betula rotundifolia, $1840 \mathrm{~m}$ a.s.1., soil sample $(0-10 \mathrm{~cm}$ deep), 17-18.VII.2006, leg. P.N., J.N.

DISTRIBUTION. Being originally described by Stuxberg $[1876 \mathrm{a}, \mathrm{b}]$ from the Yenisei River region, Krasnoyarsk Province, central Siberia, L. (M.) nordenskioeldii was redescribed a century later by Eason [1976] from Stuxberg's type material with a designation of a lectotype. This species provisionally recently found in the Republic of Altai (near Lake Teletskoye) [Nefediev et al., 2017a] and the Altai Province [Nefediev et al., 2017b, 2018], both SW Siberia.
REMARKS. The above is the first confirmed record of L. (M.) nordenskioeldii in the Republic of Altai, expanding the southeastern range limit of the species.

\section{Lithobius (Monotarsobius) worogowensis Eason, 1976 \\ Map 2.}

Monotarsobius worogowensis Eason, 1976: 120, 121: figs

Monotarsobius worogowensis - Zalesskaja, 1978: 153, figs; Vorobiova, 1999: 33; Rybalov, 2002: 82; Vorobiova et al., 2002: 61.

MATERIAL EXAMINED. 1 ○ (PSU-813), Russia, Republic of Khakassia, Ust-Abakan District, valley of Uibat River, 53. $825765^{\circ} \mathrm{N}, 90.052647^{\circ} \mathrm{E}$, mixed forest, ca $700 \mathrm{~m}$ a.s.1., in litter, 17. VII.2012, leg. A.M

DISTRIBUTION. Originally described by Eason [1976] from Stuxberg's type material of $L$. (M.) nordenskioeldii and $L$. vagabundus, this species was later recorded also from the Yenisei River region [Vorobiova, 1999; Rybalov, 2002; Vorobiova et al., 2002].

REMARKS. The above male of $L$. (M.) worogowensis, taken in the Republic of Khakassia, is the first regional and southernmost record of this species.

\section{Conclusions}

The above new records of all 13 species clarify their distribution areas in Siberia. Two species, Lithobius (Ezembius) giganteus Sseliwanoff, 1881 and $L$. (Chinobius) opinatus (Zalesskaja, 1978), the subgenus Chinobius Matic, 1973, the latter species belongs to, are new to western Siberia. Five species, $L$. (Ch.) opinatus (Zalesskaja, 1978), L. (E.) princeps Stuxberg, 1876, L. (Monotarsobius) curtipes C.L. Koch, 1847, L. (M.) fugax Stuxberg, 1876 and L. (M.) worogowensis Eason, 1976, as well as the genus Lithobius Leach, 1814, and three subgenera, Chinobius Matic, 1973, Ezembius Chamberlin, 1919 and Monotarsobius Verhoeff, 1905, and the family Lithobiidae they all belong to, are formally recorded from the Republic of Khakassia for the first time. Two species, L. (E.) giganteus Sseliwanoff, 1881 and L. (M.) fugax Stuxberg, 1876, are formally new to the Republic of Altai. Lithobius (M.) nordenskioeldii Stuxberg, 1876 is also confirmed for its presence in the Republic of Altai.

Acknowledgements. We are very thankful to S.I. Golovatch (Moscow, Russia) who kindly checked the English of an advanced draft. Our deepest gratitude is extended to all persons who provided material for the present study: S.V. Dragan (Abakan, Russia), M.V. Shcherbakov (Tomsk, Russia), T.M. Krugova (Barnaul, Russia), and V.I. Gusarov, M.F. Maurstad, V. Løveng (all Oslo, Norway).

\section{References}

Alekseeva E.E. 1974. [Soil mesofauna of steppes and forests in western Transbaikalia]. Autoreferate of the Thesis of Candidate (Ph.D.) of Biological Sci. Degree. Moscow. 20 p. [In Russian]

Attems C.G. 1909. Die Myriopoden der Vega-Expedition // Arkiv för Zoologi. Bd.5. No.3. S.1-84. 
Bukhkalo S.P., Galitch D.E., Sergeeva E.V., Vazhenina N.V. 2014 [Synopsis of the invertebrate fauna of the southern taiga in western Siberia (basin of the Lower Irtysh)]. Moscow: KMK Scientific Press. 189 p. [In Russian]

Bukhkalo S.P., Sergeeva E.V. 2012. [Interannual dynamics of the composition and structure of soil invertebrate communities in the root terrace of Irtysh River] // Belgorod State Univ. Scientific Bulletin. Natural Sciences. No.5(134). Iss.20. P.59-64 [in Russian].

Chamberlin R.V. 1919. The Chilopoda collected by the Canadian Arctic Expedition, 1913-18 // Report of the Canadian Arctic Expedition 1913-18. Vol.3: Insects. Part H: Spiders, Acarina, Chilopoda. Ottawa: J. de Labroquerie Taché. P.15-22.

Chamberlin R.V. 1923. Chilopoda // A biological survey of the Pribilof Islands, Alaska. II. Insects, arachnids and chilopods. North American Fauna. No.46. P.240-244.

Chornyi M.G., Kosyanenko O.W. 2003. [Millipedes and centipedes of the Middle Dnieper area] // Zapovidna sprava $\mathrm{V}$ Ukraini. Vol.9. No.2. P.64-66 [in Ukrainian].

Dányi L., Tuf I.H. 2012. Lithobius (Monotarsobius) franciscorum sp. nov., a new lithobiid species from the Altai, with a key to the Central Asian species of the subgenus (Chilopoda: Lithobiomorpha) // Zootaxa. Vol.3182. P.16-28.

Dobroruka L.J. 1960. Ueber eine kleine Chilopoden-Ausbeute aus der Mongolie // Acta Arachnologica. Vol.17. No.1. S.15-18

Dobroruka L.J. 1970. Kurzer Beitrag zur Kenntnis der zentralaisatischen Chilopoden // Zoologischer Anzeiger. Bd.184. H.1/ 2. S.94-96.

Dobroruka L.J. 1979. Zur weiteren Kenntnis der zentralaisatischen Chilopoden // Vìstník Ėeskoslovenské spoleènosti zoologické. Vol.43. No.3. S.161-164.

Dyachkov Yu.V. 2017a. New records of lithobiid centipedes (Chilopoda: Lithobiomorpha) from western Mongolia // Far Eastern Entomologist. No.345. P.34-36.

Dyachkov Yu.V. 2017b. [The first data on the centipede (Chilopoda: Geophilomorpha; Lithobiomorpha) fauna of the Katun Biosphere State Nature Reserve, Altai Mts] // Ukrainian Journal of Ecology. Vol.7. No.4. P.453-456 [in Russian, with English summary].

Dyachkov Yu.V. 2019. New data on lithobiomorph centipedes (Chilopoda: Lithobiomorpha: Anopsobiidae, Henicopidae, Lithobiidae) from Kazakhstan // Arthropoda Selecta. Vol.28. No.1. P.8-20. doi: 10.15298/arthsel. 28.1.02.

Eason E.H. 1976. The type specimens and identity of the Siberian species described in the genus Lithobius by Anton Stuxberg in 1876 (Chilopoda: Lithobiomorpha) // Zoological Journal of the Linnean Society. No.58. P.98-127.

Farzalieva G.Sh. 2018. Lithobius (Monotarsobius) tanagolus sp.n., a new lithobiid species (Chilopoda, Lithobiomorpha) from southern Siberia, with remarks on the closely related $L$. (M.) holstii (Pocock, 1895) // Arthropoda Selecta. Vol.27. No.1. P.22-30.

Farzalieva G.Sh., Esyunin S.L. 2008. A review of the centipede (Lithobiomorpha, Henicopidae, Lithobiidae) fauna of the Urals and Cis-Ural area // Entomological Review. Vol.88. No.5. P.598-623. https://doi.org/10.1134/S0013873808050102.

Farzalieva G.Sh., Nefediev P.S. 2018. The first record of the anopsobiid genus Shikokuobius Shinohara, 1982 in continental Asia, with the description of a new species from the Altais, southwestern Siberia, Russia (Chilopoda, Lithobiomorpha, Anopsobiidae) // ZooKeys. Vol.793. P.15-28. https://doi.org/10.3897/ zookeys.793.29221.

Farzalieva G.Sh., Nefediev P.S., Tuf I.H. 2017. Lithobius (Chinobius) yuchernovi, a new lithobiid species from northeastern Siberia and the Kamchatka Peninsula, Russia (Chilopoda, Lithobiomorpha) // ZooKeys. Vol.693. P.95-108. https://doi.org/ 10.3897/zookeys.693.14769.

Gerstfeldt G. 1859. Ueber einige zum Theil neue Arten Platoden, Anneliden, Myriapoden und Crustaceen Sibiriens, namentlich seines östlichen Theiles und des Amur-Gebiets // Mémoires L'Académie Impériale des Sciences. St. Petersbourg. T.8. S.136.

Haase E. 1880. Zur Kenntnis der sibirischen Myriapoden // Zoologischer Anzeiger. Bd.3. No.55. S.223-225.
Kurcheva G.F. 1977. [Soil invertebrates of the Soviet Far East]. Moscow: Nauka Publ. 132 p. [In Russian]

Loksa I. 1965. Zoologische Ergebnisse der Forschungen von Dr. Z. Kaszab in der Mongolei. 21. Chilopoda // Opuscula Zoologica, Instituti Zoosystematici et Oecologici Universitatis Budapestinensis. T.5. No.2. S.199-215.

Loksa I. 1978. Chilopoden aus der Mongolei (Arthropoda: Tracheata, Chilopoda) // Annales Historico-Naturales Musei Nationalis Hungarici. Vol.70. S.111-120.

Lignau N. 1929. Zur Kenntnis der zentralasiatischen Myriopoden // Zoologischer Anzeiger. Bd.85. H.5/8. S.159-175.

Molodova L.P. 1972. [Soil invertebrates of southern Sakhalin and their significance for soil characteristics]. Autoreferate of the Thesis of Candidate (Ph.D.) of Biological Sci. Degree. Moscow. 29 p. [In Russian]

Muralewitsch W.S. 1906. Myriapoden, gesammelt von der Expedition nach der Halbinsen Kanin im Jahre 1902 // Zoologischer Anzeiger. Bd.30. H.3/4. S.66-69.

Nefediev P.S. 2001. [On the fauna and ecology of Myriapoda in the environs of the village of Smolenskoe, Altai Province] // Landshafty Zapadnoi Sibiri: problemy issledovaniy, ekologiya i ratsionalnoe ispolzovanie. Materialy VII Mezhdunarodnoi mezhvuzovskoi konferentsii, posvyashchyonnoi Dnyu Zemli. Biysk: Biysk Pedagogical State Univ. Publ. P.84-86 [in Russian].

Nefediev P.S., Aripov V.S. 2013. [The history of the study of biodiversity of centipedes (Chilopoda) in Siberia in XIX century] // Sbornik nauchnykh statei mezhdunarodnoi molodiozhnoi shkoly-seminara "Lomonosovskie chteniya na Altaye". Barnaul: Altai State University Publ. Vol.6. P.40-42 [in Russian].

Nefediev P.S., Farzalieva G.Sh., Tuf I.H. 2017a. A preliminary review of the fauna of the Altai State Nature Biosphere Reserve, southwestern Siberia, Russia (Chilopoda: Lithobiomorpha, Geophilomorpha) // Arthropoda Selecta. Vol.26. No.3. P.217-224.

Nefediev P.S., Farzalieva G.Sh., Tuf I.H., Efimov D.A. 2020. The first records of lithobiid centipedes (Chilopoda: Lithobiomorpha: Lithobiidae) from the Kemerovo Area, southwestern Siberia, Russia // Invertebrate Zoology. Vol.17. No.1. P.36-43.

Nefediev P.S., Farzalieva G.Sh., Tuf I.H., Nedoev H.Kh., Niyazov S.T. 2017b. Millipede and centipede assemblages on the northern and southern slopes of the lowland Altais, southwestern Siberia, Russia (Diplopoda, Chilopoda) // Tropical Natural History. Suppl.5. $17^{\text {th }}$ International Congress of Myriapodology. 23-26 July 2017, Krabi, Thailand. Book of abstracts. P.13.

Nefediev P.S., Farzalieva G.Sh., Tuf I.H., Nedoev Kh.Kh., Niyazov S.T. 2018. Millipede and centipede assemblages on the northern and southern slopes of the lowland Altais, southwestern Siberia, Russia (Diplopoda, Chilopoda) // Stoev P., Edgecombe G.D. (eds.). Proceedings of the $17^{\text {th }}$ International Congress of Myriapodology, Krabi, Thailand. ZooKeys. Vol.741. P.219254. https://doi.org/10.3897/zookeys.741.21936.

Nefediev P.S., Knyazev S.Yu., Farzalieva G.Sh., Tuf I.H. 2017c. A contribution to the myriapod fauna of the Omsk Area, Siberia, Russia (Myriapoda: Diplopoda, Chilopoda) // Arthropoda Selecta. Vol.26. No.2. P.113-118.

Nefediev P.S., Tuf I.H., Farzalieva G.Sh. 2016. Centipedes from urban areas in southwestern Siberia, Russia (Chilopoda). Part 1. Lithobiomorpha // Arthropoda Selecta. Vol.25. No.3. P.257266.

Poloczek A., Pfeiffer M., Schneider R., Müchlenberg M. 2016. The Chilopoda (Myriapoda) of the Khentey-Mountain Range, Northern Mongolia. Communities of different forest-types under a varying fire regime // European Journal of Soil Biology. Vol.74. P.114-120.

Rybalov L.B. 2002. [Zonal and landscape changes in soil invertebrate populations in a near-Yenisei River region of Middle Siberia and the role of temperature adaptations in the meridional (zonal) distribution of invertebrates] // Russian Entomological Journal. Vol.11. No.1. P.77-86 [in Russian, with English summary].

Sergeeva E.V. 2010. [Species diversity of centipedes (Chilopoda) in the southern taiga subzone of Western Siberia] // Proceed- 
ings of the All-Russian scientific and practical conference "Scientific Tobolsk - 2010". Tobolsk. P.37-39 [in Russian].

Sergeeva E.V. 2013. [Biotopic distribution and the numbers of centipedes (Chilopoda) in the Irtysh valley of West Siberia, Russia] // Euroasian Entomological Journal. Vol.12. No.6. P.529-533 [in Russian, with English summary].

Sseliwanoff A.W. 1880a. Eine Bemerkung über "Lithobius sibiricus" Gerstfeldt's // Zoologischer Anzeiger. Bd.3. No.68. S.541543.

Sseliwanoff A.V. 1880b. [Materials towards the study of Russian myriapods. I. Chilopoda] // Trudy Russkogo Entomologicheskogo Obshchestva. T.11. P.3-26 [in Russian].

Sseliwanoff A.V. 1881a. [Lithobiidae deposited in the Museum of the Imperial Academy of Sciences] // Zapiski Akademii Nauk. St. Petersburg. Vol.37. No.1. P.1-19 [in Russian].

Sseliwanoff A.V. 1881b. Neue Lithobiiden aus Sibirien und Central-Asien // Zoologischer Anzeiger. Bd.4. No.73. S.15-17.

Striganova B.R., Poryadina N.M. 2005. [Soil animal population in boreal forests of the West-Siberian Plain]. Moscow: KMK Scientific Press. 234 p. [In Russian]

Stuxberg A. 1876a. Myriopoder från Sibirien och Waigatsch ön samlade under Nordenskiöldska expeditionen 1875 // Öfversigt af Kongliga Vetenskaps-Akademiens Förhandlingar. Årg.33. No.2. S.11-38.

Stuxberg A. 1876b. On the Myriopoda, from Siberia and Waigatsch Island, collected during the expedition of Prof. Nordenskiöld, 1875 // Annals and Magazine of Natural History. Ser.4. Vol.17. P.306-318, doi: 10.1080/00222937608681955.

Tuf I.H. 2007. [Diversity of selected taxa of invertebrates in the Altai (East Kazakhstan)] // Modern approaches to biodiversity protection in the context of steady development achievement of the Republic of Kazakhstan. Proceedings of the International Kazakh-Czech Scientific Conference, Ust-Kamenogorsk. P.56-64 [in Czech, with English summary].
Tuf I.H., Dányi L., Kuda F., Chlachula J. 2010. Centipedes of Kazakhstan - new records from Altai // High Mountain Soils Biodiversity. Tbilisi. P.11-12.

Verhoeff K.W. 1934 (for 1933). Schwedisch-chinesische wissenschaftliche Expedition nach den nordwestlichen Provinzen Chinas, unter Leitung von Dr. Sven Hedin und Prof. Sü Pingchang. Myriapoda gesammelt vom schwedischen Arzt der Expedition Dr. David Hummel 1927-1930 // Arkiv för Zoologi. Bd.26A. No.10. S.1-41.

Vorobiova I.G. 1999. [Ecological and faunistic characteristics of myriapod populations in the mid-flow region of Yenisei River] // Problemy pochvennoi zoologii. Materialy II (XII) Vserossiyskogo soveschaniya po pochvennoi zoologii. Moscow: KMK Scientific Press. P.33-34 [in Russian].

Vorobiova I.G., Rybalov L.B., Rossolimo T.E., Zalesskaja N.T. 2002. [Zonal and landscape distributions of the myriapod fauna and populations (Myriapoda) in the Yenisei River basin] // Izuchenie, sokhranenie i vosstanovlenie bioraznoobraziya ekosistem na Yeniseiskom ekologicheskom transekte: Zhivotnyi mir, etno-ekologicheskie issledovniya, 2. Moscow: IEE RAS. P.60-71 [in Russian].

Wytwer J., Tajovský K. 2019. The Siberian centipede species Lithobius proximus Sseliwanoff, 1878 (Chilopoda, Lithobiomorpha): a new member of the Polish fauna // ZooKeys. Vol.821. P.1-10. doi: 10.3897/zookeys.821.32250.

Zalesskaja N.T. 1973. [Ecological and morphological features of Lithobiomorpha of the main soil and vegetation zones of the USSR]. Thesis of Candidate (Ph.D.) of Biological Sci. Degree. Moscow. 160 p. [In Russian]

Zalesskaja N.T. 1978. [Identification book of the lithobiomorph centipedes of the USSR]. Moscow: Nauka Publ. 212 p. [In Russian]

Responsible editor S.I. Golovatch 